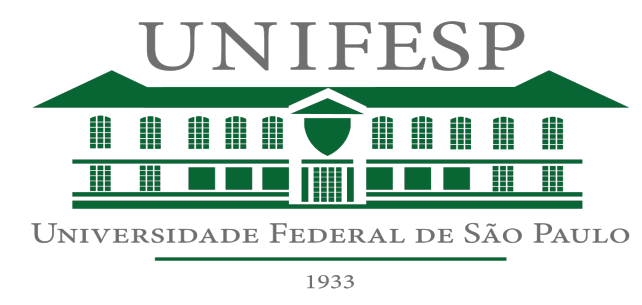

UNIVERSIDADE FEDERAL DE SÃO PAULO DEPARTAMENTO DE CIÊNCIAS DO MAR

UNIDADE BAIXADA SANTISTA - SP

ENGENHARIA DE PETRÓLEO

FILIPE BRANDÃO MATTAR

PROPOSTA DE GERAÇÃO FOTOVOLTAICA PARA O EDIFÍCIO CARVALHO DE MENDONÇA DA UNIVERSIDADE FEDERAL DE SÃO PAULO CAMPUS BAIXADA SANTISTA 
FILIPE BRANDÃO MATTAR

\section{PROPOSTA DE GERAÇÃO FOTOVOLTAICA PARA O EDIFÍCIO CARVALHO DE MENDONÇA DA UNIVERSIDADE FEDERAL DE SÃO PAULO CAMPUS BAIXADA SANTISTA}

Monografia submetida ao curso de graduação em Engenharia de Petróleo, como requisito parcial para a obtenção do Título de Bacharel em Engenharia de Petróleo

Orientador: Prof. Dr. Fernando Ramos Martins Co-orientador: Prof. Dr. Cledson Akio Sakurai

Santos - SP 
BIBLIOTECA 
A meus pais Elzo e Dunia por seu amor incondicional e apoio em todos os momentos. 


\section{AGRADECIMENTOS}

Primeiramente, agradeço a Deus pelo dom da vida. Agradeço também à minha família, principalmente aos meus pais, Elzo e Dunia e irmã Mylla, pois o verdadeiro amor e felicidade estão na própria casa.

Ao Prof. Fernando Ramos Martins, pela orientação, pela paciência e dedicação, e pelos conhecimentos compartilhados durante a realização deste trabalho. Também a todos os professores do Departamento de Ciências do Mar pelos ensinamentos e que foram tão importantes na minha formação e na vida acadêmica.

A meu tio Carlos Alberto Mattar por todos os conselhos e apoio durante o meu

processo de formação, e pela paciência nos esclarecimentos sobre detalhes essências e imprescindíveis para a realização deste trabalho.

À minha namorada Paula, por sempre fazer com que eu acreditasse em mim mesmo. Por ser companheira e amiga em todos os momentos.

Aos amigos Rafael, Thalles, Ciro e Leandro por terem se mostrado verdadeiros irmãos durante toda a formação. Também às grandes amizades feitas neste período, e sem vocês o caminho seria mais difícil. 


\section{RESUMO}

A energia solar terá papel fundamental na diversificação da matriz energética brasileira devido aos altos índices de irradiação em todo o território e com aspectos regulatórios (Resolução Normativa $n^{\circ}$ 687/2015) favoráveis ao desenvolvimento desta fonte energética. Desta forma, é proposto e simulado três diferentes sistemas fotovoltaicos na cobertura do edifício Carvalho de Mendonça da Universidade Federal de São Paulo campus Baixada Santista a fim de servirem como fonte de eletricidade, assim como laboratórios para pesquisa e ensino. Com o auxílio do software do National Renewable Energy Laboratory (NREL) chamado System Advisor Model (SAM), foram simuladas três plantas: a Instalação 1 com orientação para Norte, com 64 módulos de silício multi-cristalino com potência de 16,294 $\mathrm{kW}_{\mathrm{p}}$; a Instalação 2 com orientação para o Sul, com 10 módulos de Disseleneto de Cobre, índio e Gálio (CIGS) e potência de 2,281 kW ; e a Instalação 3 também com orientação para o Sul, com 7 módulos de silício monocristalino e potência de $1,890 \mathrm{~kW}_{\mathrm{p}}$. Após as simulações, as Instalações 1, 2 e 3 apresentaram respectivamente um Performance Ratio (PR) de 70\%, $63 \%$ e $69 \%$ e um fator de capacidade de $10,4 \%, 7,7 \%$ e $7,8 \%$. Os resultados se mostraram abaixo do esperado, principalmente para a Instalação 1, uma vez que é necessária uma base de dados meteorológicos mais consistente e com uma ferramenta para determinação de sombreamento mais precisa que a disponível no software. Entretanto, os sistemas fotovoltaicos se mostraram como excelentes investimentos não apenas em eficiência energética e sustentabilidade, mas também como ferramentas importantes para ensino e pesquisa na instituição.

\section{Palavras-chave:}


ABSTRACT 


\section{LISTA DE TABELAS}

Tabela 1: Características elétricas do módulo da Instalação 1 nas condições de referência.... 23

Tabela 2: Características mecânicas e físicas do módulo Instalação 1.................................... 24

Tabela 3: Características Elétricas do inversor da Instalação 1.............................................. 24

Tabela 4: Características elétricas do módulo da Instalação 2 nas condições de referência.... 28

Tabela 5: Características mecânicas e físicas do módulo da Instalação 2. ............................. 28

Tabela 6: Características Elétricas do inversor da Instalação 2 ........................................... 28

Tabela 7: Características elétricas do módulo da Instalação 3 nas condições de referência.... 30

Tabela 8: Características mecânicas e físicas do módulo da Instalação 3 …........................... 31

Tabela 9: Características Elétricas do inversor da Instalação 3 ............................................. 31

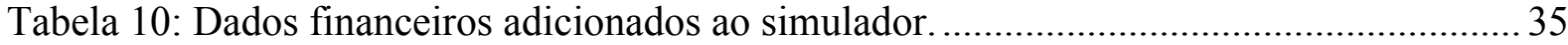

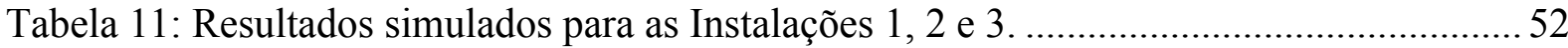




\section{LISTA DE FIGURAS}

Figura 1: Oferta Interna Nacional de Energia Elétrica por fonte. ........................................ 12

Figura 2: Mapa da média anual do total diário da irradiação global horizontal....................... 14

Figura 3: Comparação entre os níveis de irradiação global horizontal do Brasil com relação a Alemanha, Espanha e França.

Figura 4: Comparativo entre os níveis de irradiação global horizontal das cinco regiões brasileiras.

Figura 5: Número de conexões por tipo de fonte até 22/08/2017.

Figura 6: Perspectivas de redução de custo para sistemas fotovoltaicos 19

Figura 7: Número acumulado de unidades consumidoras com geração distribuída comparado com unidades consumidoras que recebem crédito 20

Figura 8: Módulo Canadian Solar CS6P - 255P: 1,638 x 0,982m 23

Figura 9: Esquema da disposição dos módulos e dos inversores da Instalação 1. 25

Figura 10: Desenho da Instalação 1 na faixada Norte do edifício, Vista Superior. 25

Figura 11: Vista lateral da cobertura da faixada Norte contendo a Instalação 1..................... 26

Figura 12:Módulo MiaSolé Flex-02 220W: 1,722x0,993m................................................ 27

Figura 13: Esquema da disposição dos módulos e dos inversores da Instalação 2 .................. 29

Figura 14: Desenho da Instalação 2 na faixada Sul do edifício, Vista Superior. 29

Figura 15: Módulo Yngli Solar YL270C-30b de 270W: 1,640x0,990m. 30

Figura 16: Esquema da disposição dos módulos e dos inversores da Instalação 3................. 32

Figura 17 Desenho da Instalação 3 na faixada Sul do edifício, Vista Superior. ....................... 32

Figura 18: Vista lateral da faixada Sul da cobertura com a Instalação 3. 33

Figura 19: Vista frontal (faixada Sul) do edifício mostrando a elevação da estrutura metálica.

Figura 20: Histograma da distribuição dos dados de irradiação global horizontal (GHI) ....... 37

Figura 21: Médias horárias de GHI dos dias separado pelos meses do ano. 38

Figura 22: Gráfico comparativo entre os valores de GHI (linha azul) e da potência gerada em kW (linha laranja) para a Instalação 1.

Figura 23: Mapa de calor indicando a GHI a esquerda e a Geração de Energia a direita ao longo das horas do dia.

Figura 24: Geração mensal de eletricidade da planta FV da Instalação 1

Figura 25: Gráfico comparativo entre temperatura da célula (curva laranja), temperatura ambiente (curva vermelha) e a eficiência do módulo (curva azul) da Instalação 1. 42 
Figura 26: Porcentagem de cada tipo de perda do sistema FV da Instalação 1.

Figura 27: Comparativo dos níveis mensais de irradiação total no plano dos módulos antes e após as perdas por sombreamento externo e soiling. 44

Figura 28: Gráfico comparativo entre os valores de GHI (linha azul) e da potência gerada em

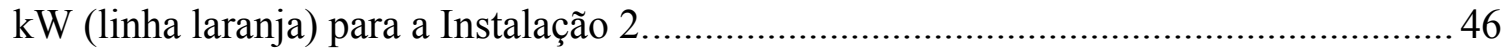

Figura 29: Geração mensal de eletricidade da planta FV da Instalação 2 .............................. 47

Figura 30: Porcentagem de cada tipo de perda do sistema FV da Instalação 2. ..................... 48

Figura 31: Gráfico comparativo entre os valores de GHI (linha azul) e da potência gerada em

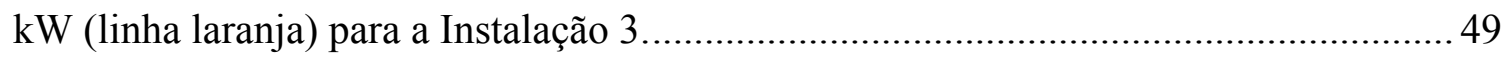

Figura 32: Geração mensal de eletricidade da planta FV da Instalação 3.............................. 50

Figura 33: Porcentagem de cada tipo de perda do sistema FV da Instalação 3. ...................... 51 


\section{SUMÁRIO}

1. INTRODUÇÃO

2. OBJETIVOS ............................................................................................................................. 15

3. FUNDAMENTAÇÃO TEÓRICA ……………………….................................................. 15

3. 1. A Energia Solar .............................................................................................................. 16

3. 2. Geração Distribuída (GD) ......................................................................................... 17

3. 3. Simuladores de Sistemas FV ............................................................................................. 20

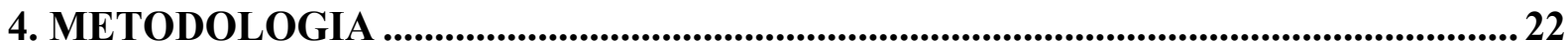

4. 1. Dados Meteorológicos e Local.....................................................................................22

4. 3. Módulos, Inversores e Design dos Sistemas ............................................................ 22

4. 4. Perdas e Sombreamento ……................................................................................... 33

4. 5. Parâmetros Financeiros................................................................................................... 35

5. RESULTADOS............................................................................................................... 37

5. 1. Instalação 1 ...................................................................................................................37

5. 2. Instalação 2 …............................................................................................................... 45

5. 3. Instalação 3 ....................................................................................................... 49

5. 4. Análise Comparativa ……………................................................................................52

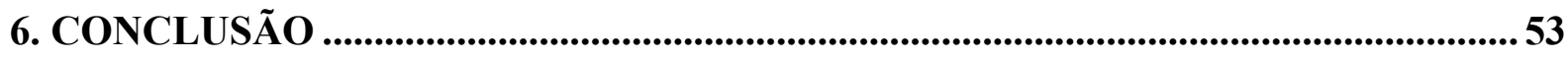

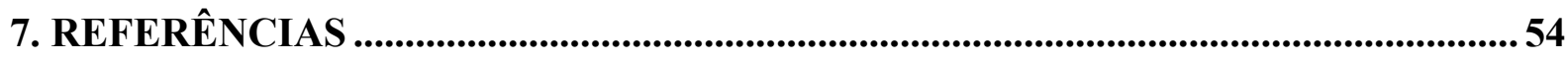




\section{INTRODUÇÃO}

A energia, nas suas mais variadas formas, é imprescindível e essencial à sobrevivência e evolução dos seres humanos (ANEEL, 2008). O fornecimento de energia primária mundial, em 2015, foi de 13.699 Mtep (Milhões de toneladas equivalente de petróleo), sendo que $81,1 \%$ provem dos combustíveis fósseis (IEA, 2016). Sendo assim, os padrões de produção e consumo de energia são nocivos ao meio ambiente com a emissão de gases de efeito estufa, tornando isto um empecilho ao suprimento de longo prazo (Goldemberg et al., 2007).

Considerando apenas a energia elétrica, o consumo mundial era no início desta década da ordem de 10 Terawatts (TW) por ano, sendo que para 2050 é projetado um consumo de 30 TW (Razykov et al., 2011). Considerando que a eletricidade é um fator estratégico para o desenvolvimento socioeconômico de um país, as fontes renováveis de energia precisarão ter papel importante no suprimento elétrico visando uma forma sustentável de atendimento de uma demanda crescente (ANEEL, 2008).

Figura 1: Oferta Interna Nacional de Energia Elétrica por fonte (Fonte: MME, 2016).

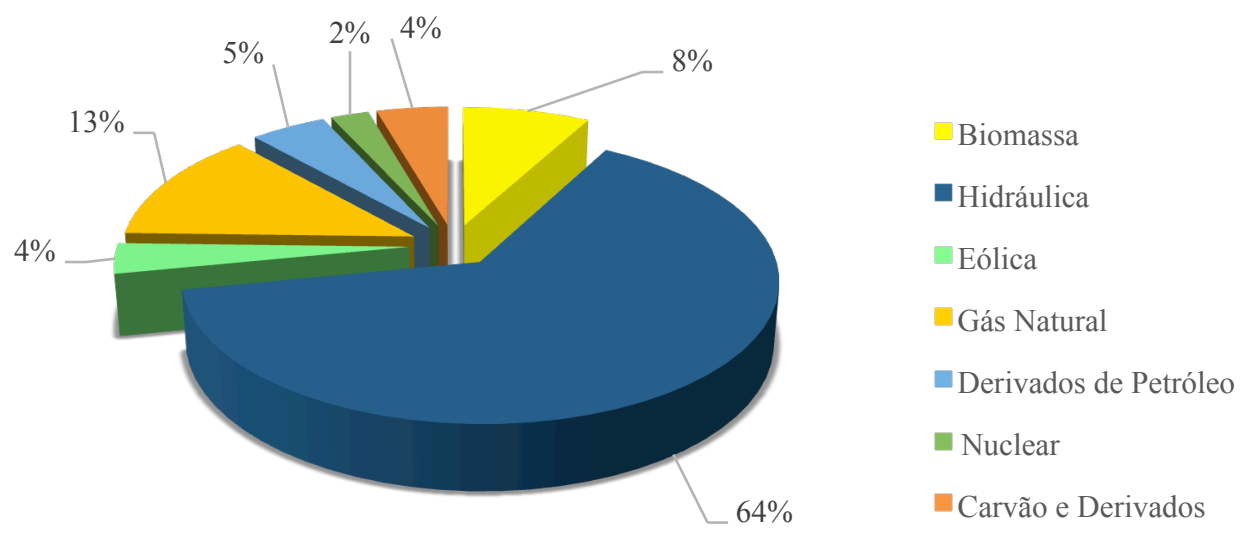

No Brasil, as fontes renováveis apresentam grande participação na matriz energética nacional sendo responsáveis por 75,51\%, conforme Figura 1 (MME, 2016). Porém, ainda se percebe uma grande predominância da fonte hídrica, o que possui risco associado aos recentes episódios de falta de ocorrência de chuva e reservatórios de acumulação com níveis baixos (ONS, 2014). Observa-se também que a energia solar ainda é pouco utilizada, não tendo 
participação significativa na oferta de eletricidade - 0,11\% de acordo com o Banco de Informação de Geração da ANEEL em agosto de 2017.

Desta forma, percebe-se que existe um grande passo a ser dado para consolidação desta fonte no país sendo que a utilização da energia solar permitiria o desenvolvimento de regiões remotas, onde o custo da eletrificação convencional é alto quando comparado ao retorno do investimento (Montenegro, 2013; Colle et al., 2004). Além disso, o uso deste tipo de energia proporcionaria uma diversificação da matriz elétrica. Este ponto está ficando cada vez mais relevante devido à vulnerabilidade do sistema elétrico nacional relacionada à variabilidade climática observada ao longo das últimas décadas e devido ao crescimento da demanda de eletricidade associada ao crescimento econômico (MME, 2016).

Uma das formas mais atrativas para fazer a melhor utilização do recurso solar é através da geração distribuída (GD), que permite uma geração descentralizada de eletricidade, reduzindo o impacto ambiental e minimizando os processos de perda de energia devido à proximidade das regiões consumidoras (ANEEL, 2014). No Brasil, o uso deste tipo de geração de eletricidade teve seu marco regulatório estabelecido em 2012 com a Resolução Normativa $n^{\circ} 482$ da Agência Nacional de Energia Elétrica Brasileira (ANEEL), que define as condições gerais de acesso à GD e ao sistema net metering. Esta regulamentação foi revisada posteriormente pela Resolução Normativa n ${ }^{\circ} 687$ de 2015.

De modo a realizar um levantamento para suporte no setor de energia solar, o Instituto Nacional de Pesquisas Espaciais (INPE) publicou o Atlas Brasileiro de Energia Solar a fim de apresentar a variabilidade do recurso ao longo do território brasileiro. Na Figura 2, podemos constatar a distribuição espacial da média anual do total diário da irradiação global horizontal, onde o valor máximo de irradiação é de $6,37 \mathrm{kWh} / \mathrm{m}^{2}$ e o mínimo de $2,95 \mathrm{kWh} / \mathrm{m}^{2}$, sendo ambos na região Sul (Pereira et al., 2017). Sendo assim, observa-se um grande potencial para aproveitamento do recurso em todas as regiões do país.

Deste modo, após os novos regulamentos e levando em consideração os altos níveis de irradiação solar observados em toda a extensão territorial do país, o uso de energia solar fotovoltaica torna-se atraente e uma ótima opção para a diversificação da matriz energética brasileira de forma sustentável (Pereira et al., 2017). 
Figura 2: Mapa da média anual do total diário da irradiação global horizontal (Fonte: Pereira et al., 2017).

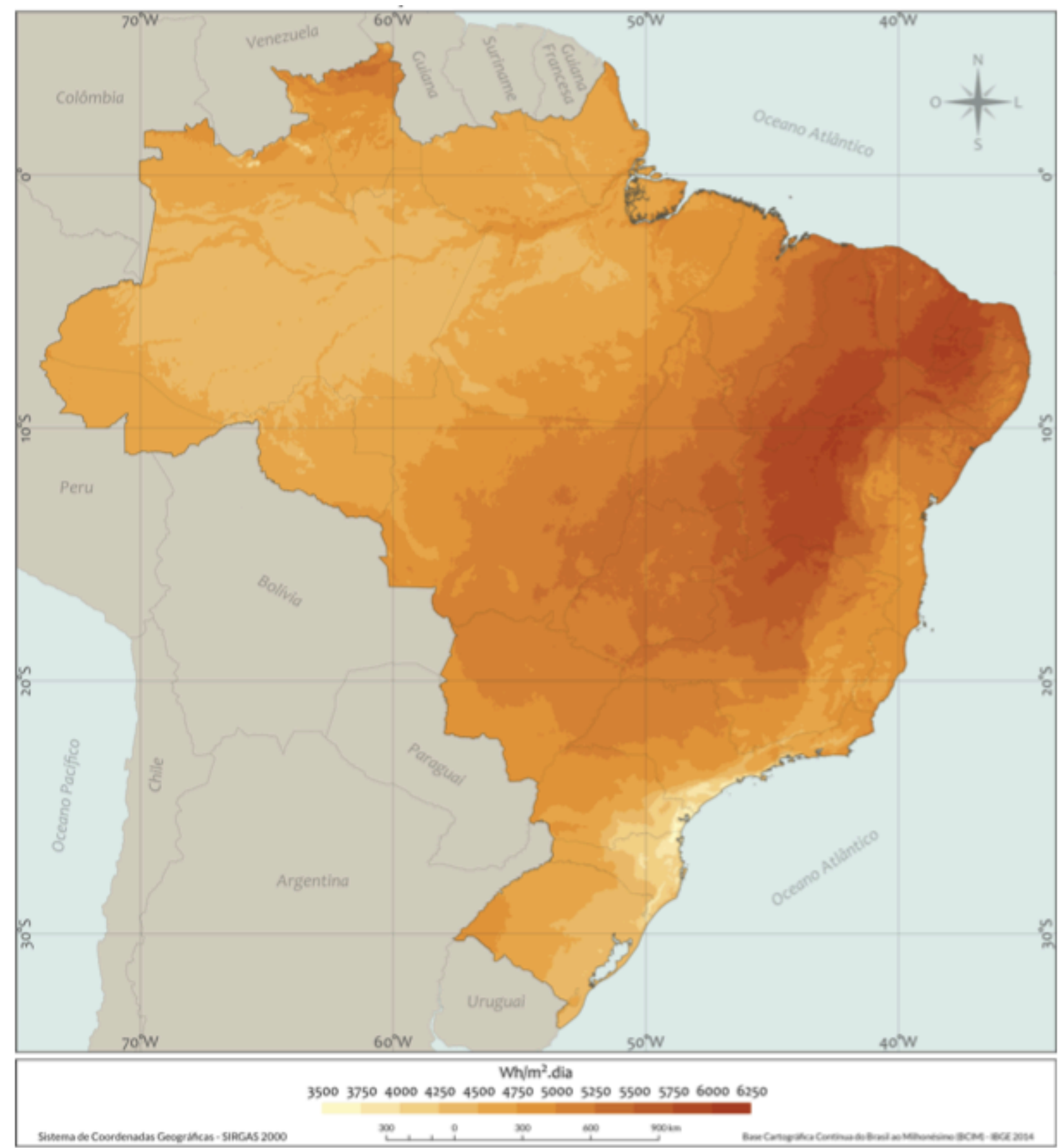




\section{OBJETIVOS}

A partir do que foi argumentado no tópico anterior, este trabalho visa simular e estimar a geração de eletricidade de plantas fotovoltaicas se instaladas no edifício Carvalho de Mendonça (CM) da Universidade Federal de São Paulo - Campus Baixada Santista, a fim de analisar e estudar as diferentes configurações dos painéis possíveis a serem adaptadas ao edifício. Sendo assim, serão propostas 3 instalações diferentes:

- Instalação 1: Sistema FV com base em tecnologia Silício Multicristalino a ser instalado na faixada Norte do edifício, com azimute de $-14^{\circ}$ (noroeste), sendo este o de maior potência instalada e o principal responsável pela produção de eletricidade;

- Instalação 2: Sistema FV com tecnologia em filme fino CIGS (Disseleneto de Cobre, Índio e Gálio) a ser instalado na faixada Sul do edifício, com azimute de $166^{\circ}$, sendo este de pequena potência instalada e com objetivo de atividade didática no curso de Engenharia de Petróleo e Recursos Renováveis;

- Instalação 3: Por último, sistema FV com de tecnologia Silício Monocristalino a ser instalado na faixada Sul do edifício, com azimute de $180^{\circ}$, sendo este de pequena potência instalada e com objetivo de atividade didática no curso de Engenharia de Petróleo e Recursos Renováveis. 


\section{FUNDAMENTAÇÃO TEÓRICA}

\section{1. A Energia Solar}

No Brasil, o Projeto SWERA (Solar and Wind Energy Resource Assessment) teve como objetivo principal promover o levantamento de uma base de dados com o intuito de auxiliar no planejamento e desenvolvimento de politicas públicas de incentivo a projetos nacionais de energia solar e eólica. O Projeto SWERA promoveu o mapeamento do potencial energético solar no Brasil, que resultou na publicação da primeira edição do Atlas Brasileiro de Energia Solar (Pereira et al., 2006).

Recentemente, o Laboratório de Modelagem e Estudos de Recursos Renováveis de Energia (LABREN) do Instituto Nacional de Pesquisas Espaciais, em colaboração com pesquisadores da UNIFESP e UFSC, publicou a segunda edição do Atlas, produzindo uma base de dados com maior confiabilidade para utilização por parte do setor elétrico (Pereira et al., 2017).

Pereira et al. (2017) destacam que o Brasil apresenta condições extremamente favoráveis a utilização deste recurso, uma vez que os altos níveis de irradiação solar aliados a baixa variabilidade são aspectos positivos em todo o território nacional. A irradiação solar na superfície alcança valores superiores aos da maioria dos países da União Europeia, onde esses recursos são amplamente aproveitados (Pereira et al., 2006).

A Figura 3 apresenta um comparativo entre os níveis de irradiação solar no país e em países onde existe uma grande aplicação de sistemas fotovoltaicos. Ou seja, é notável o potencial brasileiro do recurso solar ao longo do ano comparado aos países europeus (Espanha 1200-1850 Wh/m2; Alemanha 900-1250 kWh/m²; França 900-1650 Wh/m²).

Figura 3: Comparação entre os níveis de irradiação global horizontal do Brasil com relação a Alemanha, Espanha e França (Fonte: Pereira et al., 2017).

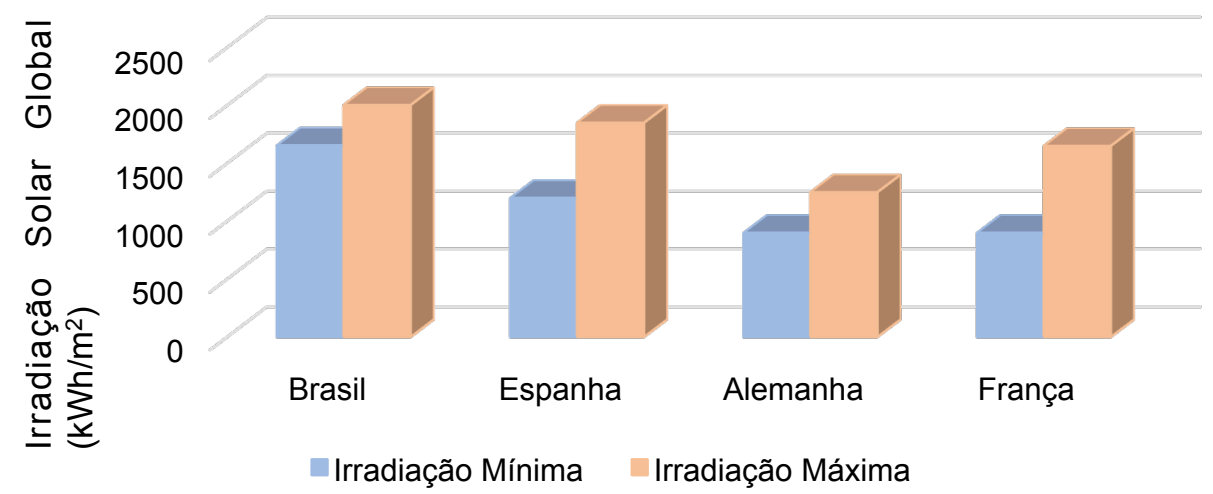


Já em uma visão mais regional, a Figura 4 faz um comparativo da média da irradiação global horizontal das cinco diferentes regiões do Brasil de acordo com Pereira et al. (2017). Ao longo de todo o território, o valor máximo extremo de irradiação global horizontal é de $6,37 \mathrm{kWh} / \mathrm{m}^{2}$ durante o verão na região Sul, ao passo que o mínimo extremo é de 2,95 $\mathrm{kWh} / \mathrm{m}^{2}$ no inverno da mesma região.

Figura 4: Comparativo entre os níveis de irradiação global horizontal das cinco regiões brasileiras (Fonte: Pereira et al., 2017).

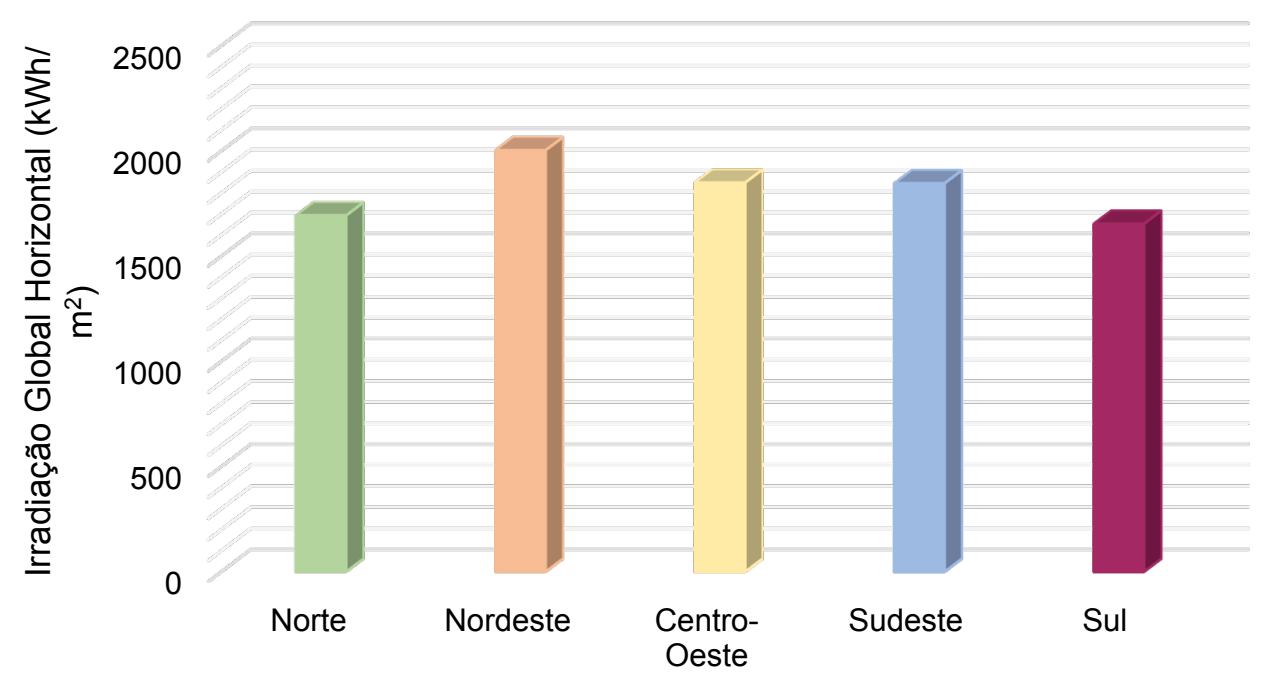

\section{2. Geração Distribuída (GD)}

Por definição, o Decreto número 5.163/2004, em seu Art. 14, considera geração distribuída sendo "a produção de energia elétrica proveniente de empreendimentos de agentes concessionários, permissionários ou autorizados [...] conectados diretamente no sistema elétrico de distribuição do comprador", mas exclui-se ainda os empreendimentos: hidrelétrico com capacidade instalada superior a $30 \mathrm{MW}$; e termelétrico, inclusive de cogeração, com eficiência energética inferior a setenta e cinco por cento, e ainda as que utilizam biomassa ou resíduos no processo, que não estarão limitadas no percentual de eficiência.

No âmbito da regulamentação da GD, a Resolução Normativa 482, aprovada em abril de 2012 pela ANEEL, estabelece algumas condições gerais para a instalação da geração distribuída de pequeno porte (tanto para a minigeração quanto para a microgeração). Se entende por microgeração, uma central geradora de energia elétrica com potência instalada menor ou igual a $100 \mathrm{~kW}$. Já a minigeração se caracteriza com potência instalada superior a 
100 kW até 1 MW (ambas estão definidas com base em energia hidráulica, eólica, solar, biomassa ou cogeração qualificada).

Esta regulamentação estabeleceu um sistema de compensação de energia elétrica (net metering), no qual a unidade consumidora está apta a instalar um gerador em sua residência, podendo injetar energia ativa na rede como forma de empréstimo a distribuidora local. Essa energia injetada é posteriormente compensada para a unidade consumidora, podendo utilizar os créditos excedentes em até 36 meses subsequentes. Vale ressaltar ainda que unidades consumidoras com mesmo CPF ou CNPJ podem utilizar os créditos gerados (ANEEL, 2012). Sendo assim, o consumo de energia elétrica a ser faturado corresponde a diferença entre a energia consumida e a injetada na rede de distribuição (ANEEL, 2014).

Em 2015, a ANEEL revisou a regulamentação para a GD através da publicação da Resolução Normativa ${ }^{0}$ 687, a fim de melhor apoiar e incentivar o mercado de energia solar. $\mathrm{O}$ novo regulamento modifica alguns aspectos do $\mathrm{REN} \mathrm{n}^{\circ} 482$ relativos aos procedimentos legais para compartilhar créditos de energia entre os parceiros associados responsáveis pela operação do sistema com a possibilidade de utilizar a GD na forma de consórcio e compartilhar esses créditos de energia entre os parceiros associados.

Embora as Resoluções da ANEEL forneçam o ambiente de condições legais para a geração distribuída, o Conselho Nacional de Política Financeira (CONFAZ) em sua publicação no estabelecimento do acordo ICMS 6 em 2013 concordou em taxar a energia gerada pelo consumidor. Este acordo fiscal criou uma barreira financeira uma vez que o consumidor era tributado duas vezes - cobrado quando a eletricidade foi despachada na rede e, posteriormente, quando compra de energia da distribuidora. No entanto, esta barreira foi superada pelo CONFAZ com a publicação publicou o Convênio ICMS 16 em 2015, revogando o Convênio ICMS 6/2013 e autorizando as unidades federais a isentar esse imposto das operações do sistema de compensação de energia. Assim, nos estados brasileiros que aderiram o acordo ICMS 16/2015, a cobrança do imposto ocorre apenas na diferença entre a energia consumida e a energia injetada na rede naquele mês (ANEEL, 2016). Para aqueles estados que não se juntaram ao novo acordo, continua valendo o anterior.

Sendo assim, percebe-se que houve uma evolução legislativa com relação a utilização de micro e minigeradores, possibilitando que consumidores se tornem pequenos geradores de eletricidade. Isso gera uma mudança importante no cenário energético nacional, melhorando a eficiência devido à proximidade da unidade geradora à unidade consumidora, e ainda aliviando as grandes centrais geradoras (usinas termo e hidrelétricas). Após pouco mais de 5 anos da primeira Resolução, percebe-se que houve uma expansão no uso de GD, com um total 
de 13.246 usinas, com uma potência instalada total de $153.755 \mathrm{~kW}$ sendo a Solar Fotovoltaica a principal fonte utilizada neste sistema, conforme ilustrado na Figura 5 (ANEEL, 2017).

Figura 5: Número de conexões por tipo de fonte até 22/08/2017 (Fonte: ANEEL, 2017).

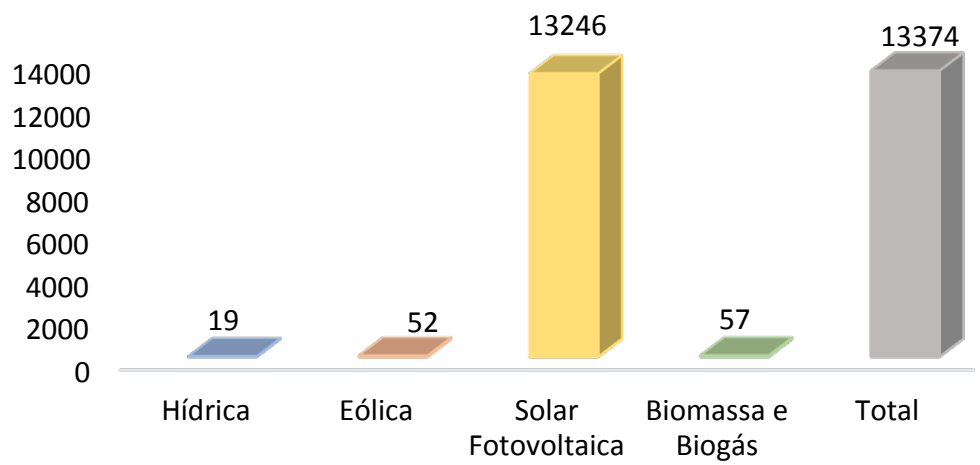

Com a expectativa de redução nos preços de sistemas fotovoltaicos (EPE, 2014) mostrados na Figura 6 e com a mudança na cobrança do ICMS sobre a energia gerada, esperase uma evolução rápida na quantidade de geradores $\mathrm{FV}$, comprovado pelo crescimento crescente do número de conexões de sistemas FV à rede de distribuição desde a publicação da $\mathrm{RN} \mathrm{n}^{0} 687 / 2015$, de acordo com os dados de conexões de Usinas Solares Fotovoltaicas em GD de (ANEEL, 2017), sintetizados na Figura 7.

Figura 6: Perspectivas de redução de custo para sistemas fotovoltaicos (Fonte: EPE, 2014).

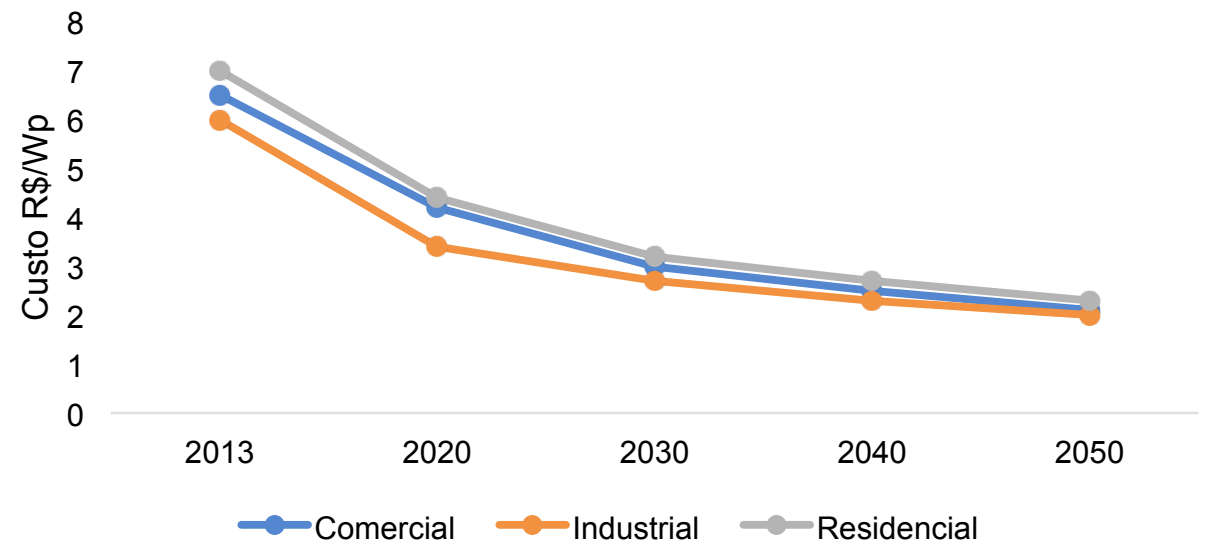

Sendo assim, observa-se um aumento exponencial na aplicação de painéis FV, totalizando em 22/08/2017 em 13.250 usinas, com potência instalada total de 106.324,92 kW. 
Vale ressaltar que a partir de 2015 a expansão se torna muito grande, o que indica o impacto da modificação da resolução, assim como da mudança na tributação do ICMS sobre a energia gerada. Outro aspecto positivo da $\operatorname{REN~n}^{\circ} 687 / 2015$ que pode ser constatado no gráfico, é o número de unidades que recebem créditos de energia é maior que o número de conexões.

Figura 7: Número acumulado de unidades consumidoras com geração distribuída comparado com unidades consumidoras que recebem crédito (Fonte: ANEEL, 2017).

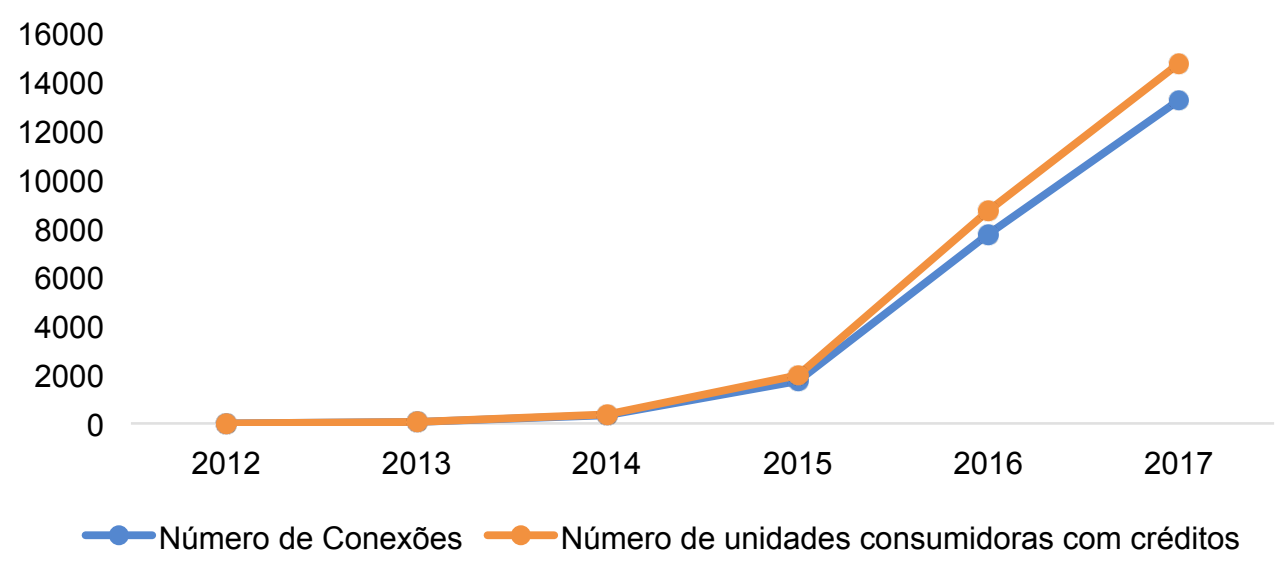

\section{3. Simuladores de Sistemas FV}

Diante da crescente demanda do mercado por sistemas fotovoltaicos conectados à rede, surge a necessidade de simulação por parte de especialistas para melhor previsão de geração de energia, assim como design do sistema e os aspectos financeiros envolvidos (Payback, Valor Presente Líquido, Taxa Interna de Retorno, entre outros). Ou seja, passou a ser necessário desenvolver plataformas computacionais baseadas em dados meteorológicos para que seja possível dimensionar sistemas fotovoltaicos com maior precisão. Dentre estas, diversos softwares se encontram disponíveis no mercado, sendo a grande maioria nãogratuitos, como revisado por Sharma et al. (2014). Serão descritos a seguir alguns programas mais tradicionais encontrados.

No ano de 2013, uma iniciativa do Instituto para o Desenvolvimento das Energias Alternativas na América Latina (IDEAL) em parceria com outras instituições produziu um modelo bem simples de simulação, encontrado no site da América do Sol. Esta ferramenta simples permite que qualquer consumidor simule seu sistema FV a partir de informações básicas como a localização da planta a ser instalada, o consumo de energia, o valor da conta e 
distribuidora local. Como resultado final, a ferramenta nos dá a potência do sistema e a geração média mensal, direcionando para um mapa contendo todos os fornecedores do país.

Dentre os softwares mais completos e com melhor detalhamento de dados a serem inseridos, podemos mencionar as ferramentas elaboradas pelo National Renewable Energy Laboratory (NREL). Dentre estes, um software bastante conceituado é o System Advisor Model (SAM), que estima o desempenho energético e de custo de energia para sistemas fotovoltaicos conectados à rede, com base em parâmetros estabelecidos pelo usuário. Neste programa, é possível inserir base de dados meteorológicos, assim como contem a base de dados de produtos de placas FV de diversos fornecedores. Ainda, existe a possibilidade de simular as perdas devidas ao sombreamento e à deposição de sujeira nos painéis. O pacote computacional também possibilita inserir modelos de financiamento existentes no mercado dos Estados Unidos. Ou seja, uma ferramenta de engenharia bastante completa que possibilita uma simulação completa, porém ainda não possui uma base de dados meteorológicos e de irradiação solar completa para o Brasil.

Outra ferramenta bastante conceituada é o PV*SOL da Valentin Software. Um simulador muito completo com um grande detalhamento dos componentes de um projeto para sistemas FV. Possui possibilidade de integração de carro elétricos, diferentes tecnologias de módulos FV, sistemas tarifários de energia (net metering), design de sistemas com baterias e off-grid, simulação de sombras baseados em mapas 3D, e ainda consegue determinar a otimização do local de instalação dos módulos tanto na vertical como horizontal, assim como performance. Conta também com análises financeiras do projeto, produzindo um fluxo de caixa detalhado. 


\section{METODOLOGIA}

\section{1. Dados Meteorológicos e Local}

Para utilização do software de simulação foi necessária a obtenção de dados de entrada para realizar a simulação de forma mais representativa. Sendo assim, a base de dados meteorológicos observados na estação meteorológica (estação de Moela) operada na região de Santos pelo INMET (Instituto Nacional de Meteorologia) foi utilizada com o intuito de obter simulações mais realistas das condições locais observadas.

De acordo com o manual do usuário do SAM, é necessária uma base de dados com pelo menos 1 ano de extensão: irradiação global horizontal, irradiação direta normal, irradiação horizontal difusa, temperatura, temperatura de ponto de orvalho, umidade relativa, pressão, velocidade e direção do vento. Os dados foram compilados em uma tabela no formato ".csv" e em conformidade com os requisitos estabelecidos para o modelo numérico adotado e minimizar incertezas ou erros de leitura do arquivo de dados. Vale ressaltar que o INMET possui apenas os dados de irradiação global.

Para dimensionar o sistema fotovoltaico (FV) a ser instalado, é necessário também considerar as dimensões do edifício onde o sistema será instalado. Desta forma, a segunda etapa de coleta de dados foi realizada junto ao departamento de Engenharia da UNIFESP campus Baixada Santista, a fim de obter as plantas com as dimensões da cobertura do edifício. As informações foram úteis para determinar o tamanho do sistema FV em função da área disponível e do modelo de painel FV a ser utilizado. Como foi realizada a simulação com diferentes tipos de painéis do mercado, os sistemas apresentaram diferentes designs.

\section{3. Módulos, Inversores e Design dos Sistemas}

O SAM possui um grande banco de dados com informações técnicas de painéis fotovoltaicos e inversores de diversos fabricantes para atender uma grande gama de potência de geração. Desta forma, foi necessário escolher um modelo de um fabricante específico para que fosse realizada a simulação dos três estudos de casos. 


\section{- Instalação 1}

Optou-se pela escolha do módulo da empresa Canadian Solar CS6P - 255P descrito na Tabela 1 e 2, uma vez que são similares aos módulos que a UNIFESP recebeu por doação. A Figura 8 mostra a imagem do módulo retirado de um catálogo do fabricante.

Figura 8: Módulo Canadian Solar CS6P - 255P: 1,638 x 0,982m (Fonte: Catálogo Canadian Solar).

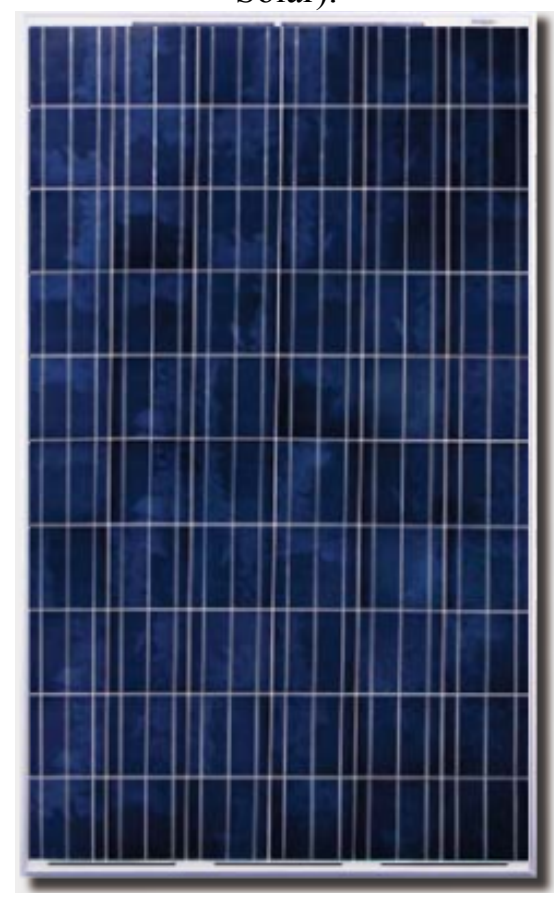

Tabela 1: Características elétricas do módulo da Instalação 1 nas condições de referência ${ }^{1}$ (Fonte: próprio Autor).

\section{Canadian Solar CS6P - 255P - Características Elétricas}

\begin{tabular}{ll} 
Eficiência Nominal & $16,44 \%$ \\
Potência Máxima (Pmp) & $255 \mathrm{~W}$ \\
Tensão de Máxima Potência (Vmp) & $30,2 \mathrm{Vcc}$ \\
Corrente de Máxima Potência (Imp) & 8,4 Acc \\
Tensão de Circuito Aberto (Voc) & 37,4 Vcc \\
Corrente de Curto-Circuito (Isc) & $9,0 \mathrm{Acc}$ \\
\hline
\end{tabular}

\footnotetext{
${ }^{1}$ As condições de referência são: Irradiação Total $=1000 \mathrm{~W} / \mathrm{m}^{2}$ e Temperatura da Célula de $25^{\circ} \mathrm{C}$.
} 
Tabela 2: Características mecânicas e físicas do módulo Instalação 1 (Fonte: Canadian Solar).

\begin{tabular}{lc}
\hline \multicolumn{2}{c}{$\begin{array}{c}\text { Canadian Solar CS5P - 255M - Características } \\
\text { Mecânicas e Físicas }\end{array}$} \\
\hline Tipo & Silício Policristalino \\
Número de Células & 60 \\
Comprimento & $1,638 \mathrm{~m}$ \\
Largura & $0,982 \mathrm{~m}$ \\
Espessura & $0,4 \mathrm{~m}$ \\
Peso & $18,0 \mathrm{Kg}$ \\
\hline
\end{tabular}

Para escolha dos inversores foi necessário o dimensionamento do sistema, de acordo com a área disponível, adaptando a melhor estrutura para o edifício e otimizando os espaços. Desta forma, a melhor configuração encontrada está apresentada na Figura 9.

Com o dimensionamento elétrico proposto, teremos um sistema com 64 módulos, sendo duas fileiras de 32 e 4 strings em parelelo, o que levará a uma potência total de 16.294 $\mathrm{W}_{\mathrm{p}}$ instalados. Sendo assim, optou-se pela escolha do inversor da Fronius, modelo Primo 8.21 descrito na Tabela 3. No total, o sistema necessitará de 2 inversores para cada fileira, o que nos dará uma razão CC/AC de 0,99 .

Tabela 3: Características Elétricas do inversor da Instalação 1 (Fonte: próprio Autor).

\begin{tabular}{ll}
\hline \multicolumn{2}{c}{ Fronius: Primo 8.2-1 } \\
\hline Potência Máxima em CA & $8200 \mathrm{~W}$ \\
Potência Máxima em CC & $8417,25 \mathrm{~W}$ \\
Potência Consumida durante uso & $37,94 \mathrm{Wcc}$ \\
Tensão Nominal CA & $240 \mathrm{Vca}$ \\
Tensão Máxima em CC & $800 \mathrm{Vcc}$ \\
Corrente Máxima em CC & $0.01 \mathrm{Acc}$ \\
Tensão Mínima de MPPT em CC & $100 \mathrm{Vcc}$ \\
Tensão Nominal em CC & $660 \mathrm{Vcc}$ \\
Tensão Máxima de MPPT em CC & $800 \mathrm{Vcc}$ \\
\hline
\end{tabular}

Para se ter um melhor aproveitamento da área, optou-se pela utilização do módulo em formato paisagem, ou seja, sua disposição seria 0,982 x 1,638m e com duas fileiras, conforme Figura 9. A Figura 10 mostra a disposição dos painéis na cobertura do edifício, sendo estes 
desenhados sob o arquivo ".dwg" obtido junto ao Departamento de Engenharia da Universidade. Desta forma, cada coluna ficou com um comprimento total de 27 metros e largura de 1,84 metros no plano horizontal, o que equivale a 2 metros no plano inclinado, conforme mostra a Figura 11.

Figura 9: Esquema da disposição dos módulos e dos inversores da Instalação 1 (Fonte: o autor).

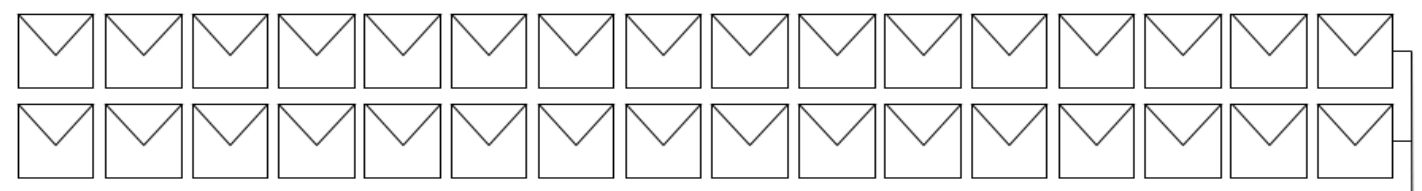

\section{Coluna 1}

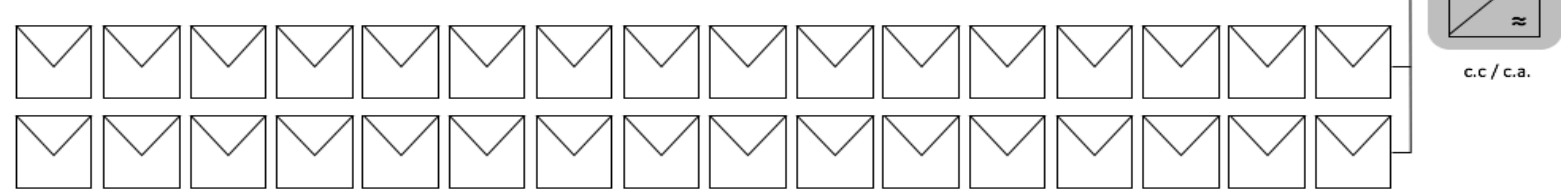

\section{Coluna 2}

Figura 10: Desenho da Instalação 1 na faixada Norte do edifício, Vista Superior (Fonte: o autor).

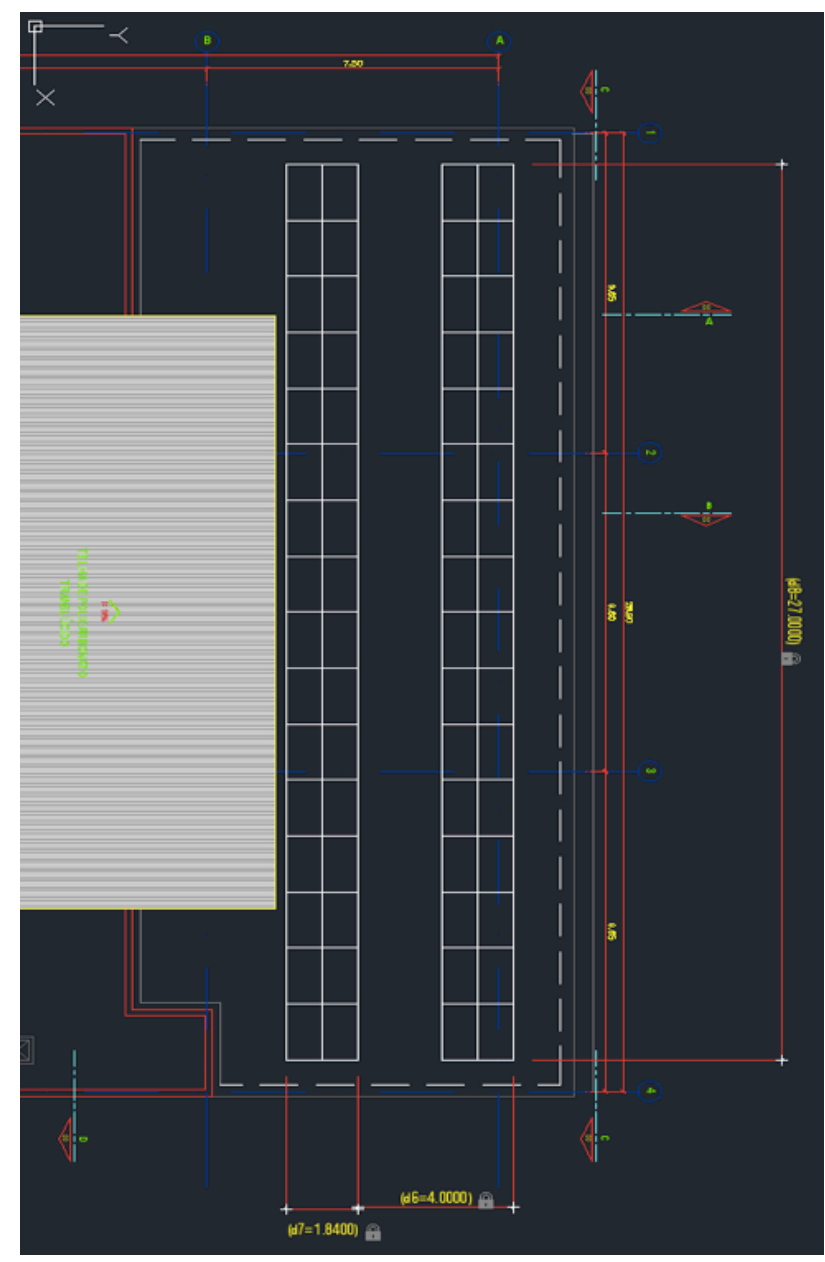


Figura 11: Vista lateral da cobertura da faixada Norte contendo a Instalação 1 (Fonte: o autor).

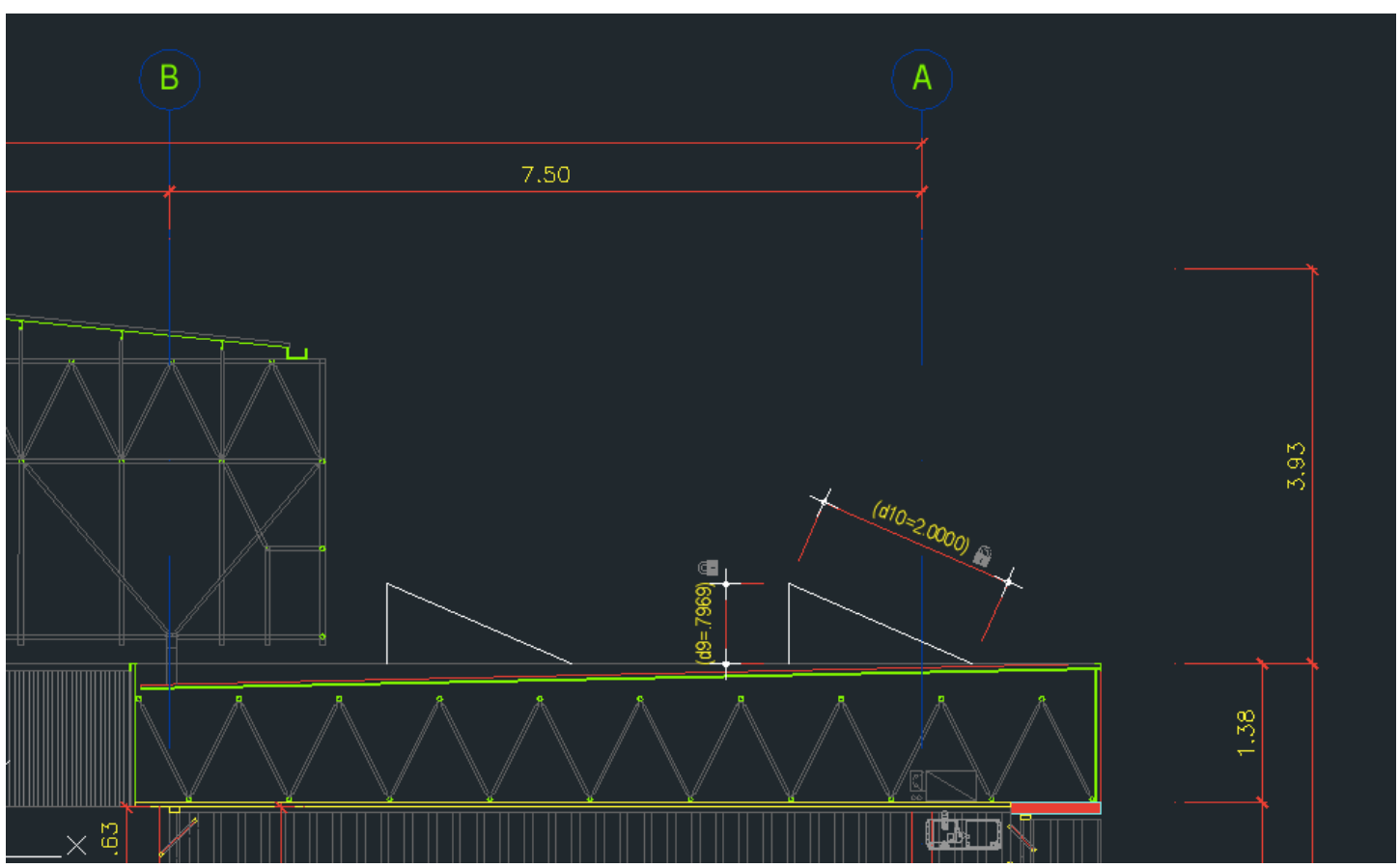

A cobertura do edifício Carvalho de Mendonça possibilitou apenas a instalação de duas fileiras, para que houvesse um espaçamento adequado evitando perdas por sombreamento e proporcionando espaço para circulação e manutenção. Para determinar a distância, foi utilizado o conceito de Ground Coverage Ratio (GCR) que indica a relação entre a área do sistema fotovoltaico e área disponível para instalação. Desta forma, de acordo com Culligan et al. (2007) um GCR de 50\% para sistemas com inclinação se mostrou um valor adequado para se utilizar neste projeto. Sendo assim, para calcularmos a distância entre as duas colunas, utiliza-se a seguinte equação:

$$
\text { Espaçamento }=\text { largura da coluna } \div G C R
$$

Este espaçamento se dá entre o início da coluna 1 e o início da coluna 2 e seu valor calculado foi de 4 metros, uma vez que a largura da coluna é de 2 metros.

Os módulos ficaram com uma inclinação de $23^{\circ}$ (próximo a latitude local de Santos), e com um azimute de $-14^{\circ}$. Tal configuração se justifica pelo fato do edifício estar com a faixada norte direcionada a $14^{\circ}$ Noroeste. Sendo assim, devido a questões de espaço e de projeto, optou-se por realizar a implementação do sistema sem direcioná-lo para o Norte geográfico e adaptando à orientação do edifício. A geometria ligeiramente a oeste possibilitará uma geração maior de eletricidade durante o período vespertino. Esse aspecto é 
bastante positivo uma vez que se estima uma curva de carga com um pico de consumo durante a tarde em decorrência da necessidade de climatização de ambientes e do maior fluxo de pessoas e horários de atividades em desenvolvimento no edifício

Vale ressaltar que, conforme a Figura 11, será necessário a implementação de uma plataforma de sustentação na faixada Norte do edifício para que seja possível a instalação de forma segura o sistema, assim como permitir o trânsito de pessoas. Com relação aos espaços para manutenção, a planta terá um recuo de 1,20 metros com relação a extremidade norte e nas laterais um espaço de 0,75 metros de cada lado da coluna de módulos.

\section{- Instalação 2}

A segunda instalação proposta no estudo opta pelo módulo da empresa MiaSolé modelo Flex-02 220W, mostrado na Figura 12. Esta opção se baseia no fato de serem módulos flexíveis e que apresentam uma eficiência alta para o tipo de tecnologia utilizado, o CIGS (14,17\%). As Tabela 4 e 5 apresentam as características elétricas e mecânicas do módulo, respectivamente.

Figura 12:Módulo MiaSolé Flex-02 220W: 1,722x0,993m (Fonte: Catálogo MiaSolé).

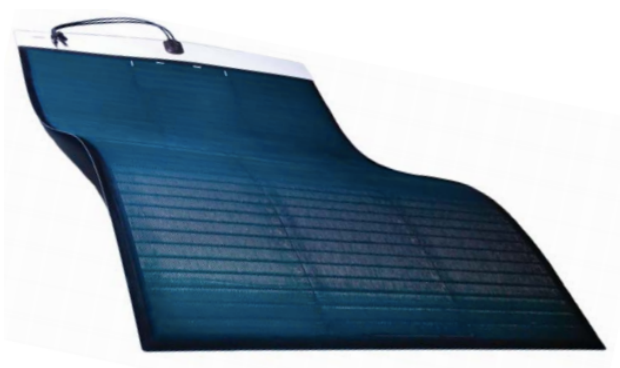

Nesta situação, o dimensionamento foi mais fácil, uma vez que se trata de um sistema de menor potência e com foco no desenvolvimento de atividades didáticas/práticas como um laboratório para curso de graduação em Engenharia. A disposição encontrada está apresentada na Figura 13.

Desta forma, a configuração encontrada foi de 10 módulos conectados em série, possuindo uma potência total instalada de 2,281 $\mathrm{kW}_{\mathrm{p}}$. O inversor selecionado para a Instalação 2 foi da empresa Fronius modelo Galvo 2.0-1 descrito na Tabela 6, com uma taxa CC/CA de 1,14. Tal escolha se deve ao fato de que nas condições de instalação deste sistema, dificilmente ele atingirá potência máxima devido a sua inclinação e direcionamento. Desta forma, a escolha por um inversor menor seria mais inteligente e com melhor custo benefício. 
Tabela 4: Características elétricas do módulo da Instalação 2 nas condições de referência. ${ }^{2}$ (Fonte: próprio Autor).

\begin{tabular}{ll}
\hline \multicolumn{2}{c}{ MiaSolé Flex-02 220W - Características Elétricas } \\
\hline Eficiência Nominal & $14,17 \%$ \\
Potência Máxima (Pmp) & $228 \mathrm{~W}$ \\
Tensão de Máxima Potência (Vmp) & $20 \mathrm{Vdc}$ \\
Corrente de Máxima Potência (Imp) & $11,4 \mathrm{Adc}$ \\
Tensão de Circuito Aberto (Voc) & $25,2 \mathrm{Vdc}$ \\
Corrente de Curto-Circuito (Isc) & $12.9 \mathrm{Adc}$ \\
\hline
\end{tabular}

Tabela 5: Características mecânicas e físicas do módulo da Instalação 2 (Fonte: MiaSolé).

\begin{tabular}{lc}
\hline \multicolumn{2}{c}{$\begin{array}{c}\text { MiaSolé Flex-02 220W - } \\
\text { Características Mecânicas e Físicas }\end{array}$} \\
\hline Tipo & CIGS \\
Número de Células & 60 \\
Comprimento & $1,722 \mathrm{~m}$ \\
Largura & $0,993 \mathrm{~m}$ \\
Espessura & $0,0025 \mathrm{~m}$ \\
Peso & $4,2 \mathrm{~kg}$ \\
\hline
\end{tabular}

Tabela 6: Características Elétricas do inversor da Instalação 2 (Fonte: próprio Autor).

\begin{tabular}{lc}
\hline \multicolumn{2}{c}{ Fronius Galvo 2.0-1 } \\
\hline Potência Máxima em CA & $2000 \mathrm{~W}$ \\
Potência Máxima em CC & $2102,51 \mathrm{~W}$ \\
Potência Consumida durante uso & $16,96 \mathrm{Wdc}$ \\
Tensão Nominal CA & $240 \mathrm{Vac}$ \\
Tensão Máxima em CC & $420 \mathrm{Vdc}$ \\
Corrente Máxima em CC & $17,8 \mathrm{Adc}$ \\
Tensão Mínima de MPPT em CC & $120 \mathrm{Vdc}$ \\
Tensão Nominal em CC & $260 \mathrm{Vdc}$ \\
Tensão Máxima de MPPT em CC & $335 \mathrm{Vdc}$ \\
\hline
\end{tabular}

${ }^{2}$ As condições de referência são: Irradiação Total $=1000 \mathrm{~W} / \mathrm{m}^{2}$ e Temperatura da Célula de $25^{\circ} \mathrm{C}$. 
Figura 13: Esquema da disposição dos módulos e dos inversores da Instalação 2 (Fonte: o autor).

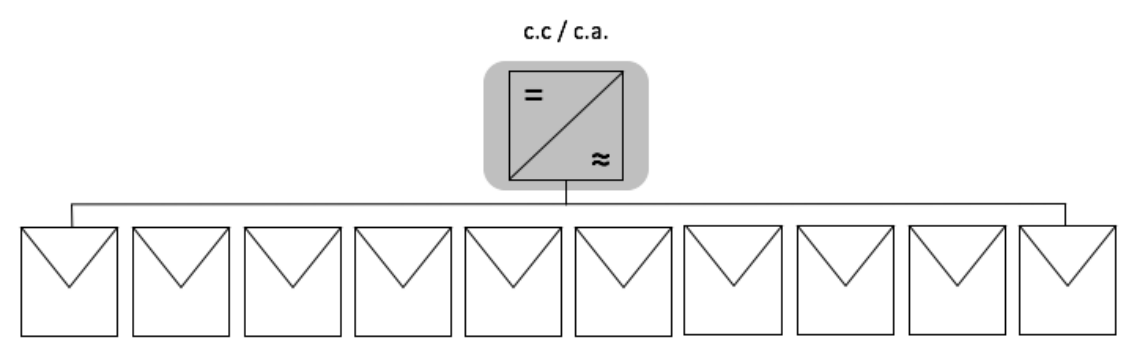

Como se trata de um sistema FV que será utilizado para atividades de ensino, os módulos serão instalados na faixada Sul do edifício e com zero inclinação, ficando totalmente planos na superfície da cobertura e com azimute de $166^{\circ}$. A Figura 14 mostra o desenho da disposição dos módulos na planilha “.dwg” com o desenho do projeto do prédio.

Figura 14: Desenho da Instalação 2 na faixada Sul do edifício, Vista Superior (Fonte: o autor).

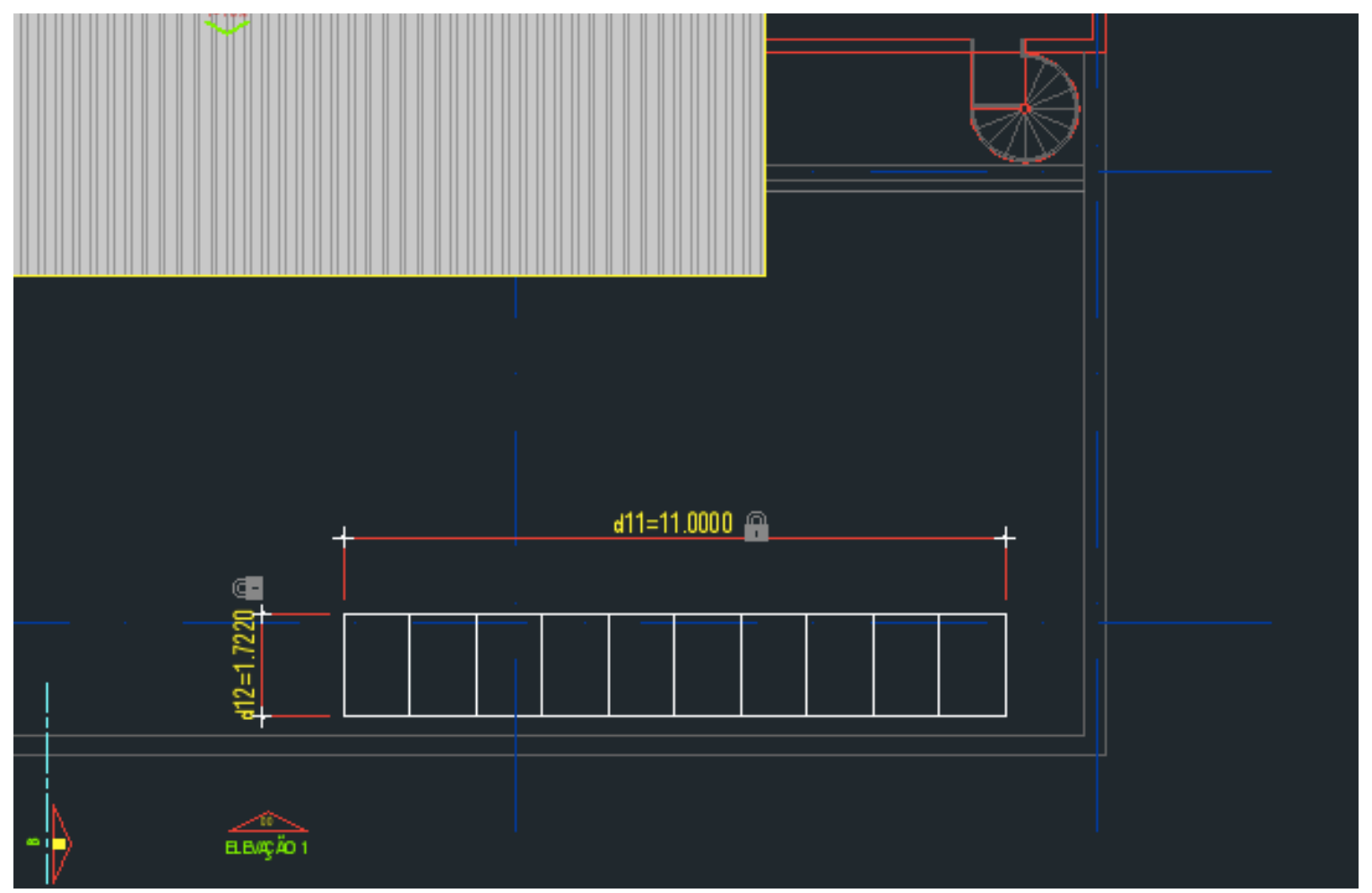

A direção dos módulos para Sul com o azimute de $166^{\circ}$ se da pelo fato do direcionamento da faixada Sul, que está a Sudeste. Neste caso, a opção é de adaptar o sistema FV ao edifício, utilizando tal instalação como ferramenta de estudo para direcionamento dos módulos e o fato de estarem no plano horizontal. Desta forma, a estrutura contará com 10 
metros de comprimento, correspondente aos 10 módulos e uma largura de 1,722 metros, sendo necessário também a adaptação da faixada, assim como na Instalação 1, para que seja possível a colocação dos módulos flexíveis de forma plana. Quanto as questões de instalação, teremos um espaçamento de 0,30 metros para faixada Sul, e com 1,32 metros para extremidade leste do edifício.

\section{- Instalação 3}

Já a terceira instalação foi feita a opção do módulo da empresa Yingli Solar modelo YL270C-30b, mostrado na Figura 15. Esta opção se baseia no fato de ser um modulo com tecnologia diferente dos utilizados nas outras instalações, sendo este de Silício Monocristalino. As Tabela 7 e 8 apresentam as características elétricas e mecânicas do módulo, respectivamente.

Figura 15: Módulo Yingli Solar YL270C-30b de 270W: 1,640x0,990m (Fonte: Catálogo Yngli Solar).

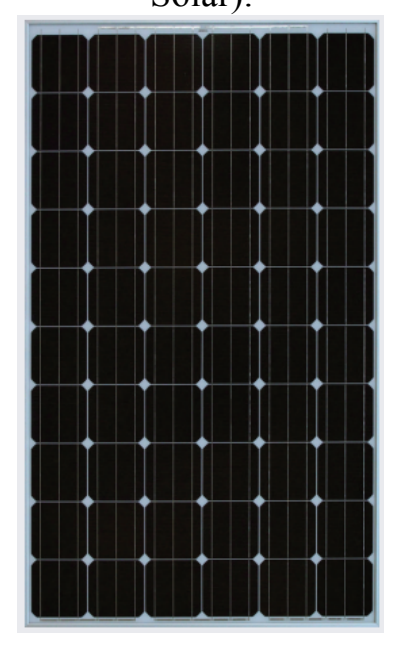

Tabela 7: Características elétricas do módulo da Instalação 3 nas condições de referência. ${ }^{3}$ (Fonte: próprio Autor).

\begin{tabular}{ll}
\hline \multicolumn{2}{c}{ Yngli Solar - YL270C-30b - Características Elétricas } \\
\hline Eficiência Nominal & $17,23 \%$ \\
Potência Máxima (Pmp) & $280 \mathrm{~W}$ \\
Tensão de Máxima Potência (Vmp) & $30,6 \mathrm{Vdc}$ \\
Corrente de Máxima Potência (Imp) & $8,8 \mathrm{Adc}$ \\
Tensão de Circuito Aberto (Voc) & $38,5 \mathrm{Vdc}$ \\
Corrente de Curto-Circuito (Isc) & $9,4 \mathrm{Adc}$ \\
\hline
\end{tabular}

\footnotetext{
${ }^{3}$ As condições de referência são: Irradiação Total $=1000 \mathrm{~W} / \mathrm{m}^{2}$ e Temperatura da Célula de $25^{\circ} \mathrm{C}$.
} 
Tabela 8: Características mecânicas e físicas do módulo da Instalação 3 (Fonte: Yingli Solar).

\begin{tabular}{lc}
\multicolumn{2}{c}{$\begin{array}{c}\text { Yngli Solar - YL270C-30b - Características } \\
\text { Mecânicas e Físicas }\end{array}$} \\
\hline Tipo & Silício Monocristalino \\
Número de Células & 60 \\
Comprimento & $1,640 \mathrm{~m}$ \\
Largura & $0,990 \mathrm{~m}$ \\
Espessura & $0,0040 \mathrm{~m}$ \\
Peso & $18,5 \mathrm{~kg}$ \\
\hline
\end{tabular}

Do mesmo modo que a Instalação 2, este sistema foi mais simples de dimensionar, uma vez que possui baixa potência instalada e será utilizado também para fins de ensino e pesquisa. O esquema dos módulos e inversor está apresentado na Figura 16.

Sendo assim, a configuração encontrada para os módulos foi de 7 módulos conectados em série, com potência total instalada de $1,890 \mathrm{~kW}_{\mathrm{p}}$. Desta forma, o inversor escolhido foi da empresa Fronius modelo Galvo 2.0-1 descrito na Tabela 9, sendo necessário apenas um inversor para o sistema, com uma taxa $\mathrm{CC} / \mathrm{CA}$ de 0,99 .

Tabela 9: Características Elétricas do inversor da Instalação 3 (Fonte: próprio Autor).

\begin{tabular}{ll}
\hline \multicolumn{2}{c}{ Fronius Galvo 2.0-1 } \\
\hline Potência Máxima em CA & $1900 \mathrm{~W}$ \\
Potência Máxima em CC & $2003,87 \mathrm{~W}$ \\
Potência Consumida durante uso & $17,36 \mathrm{Wdc}$ \\
Tensão Nominal CA & $208 \mathrm{Vac}$ \\
Tensão Máxima em CC & $420 \mathrm{Vdc}$ \\
Corrente Máxima em CC & $17.8 \mathrm{Adc}$ \\
Tensão Mínima de MPPT em CC & $120 \mathrm{Vdc}$ \\
Tensão Nominal em CC & $260 \mathrm{Vdc}$ \\
Tensão Máxima de MPPT em CC & $335 \mathrm{Vdc}$ \\
\hline
\end{tabular}


Figura 16: Esquema da disposição dos módulos e dos inversores da Instalação 3 (Fonte: o autor).

\section{c.c/ c.a.}

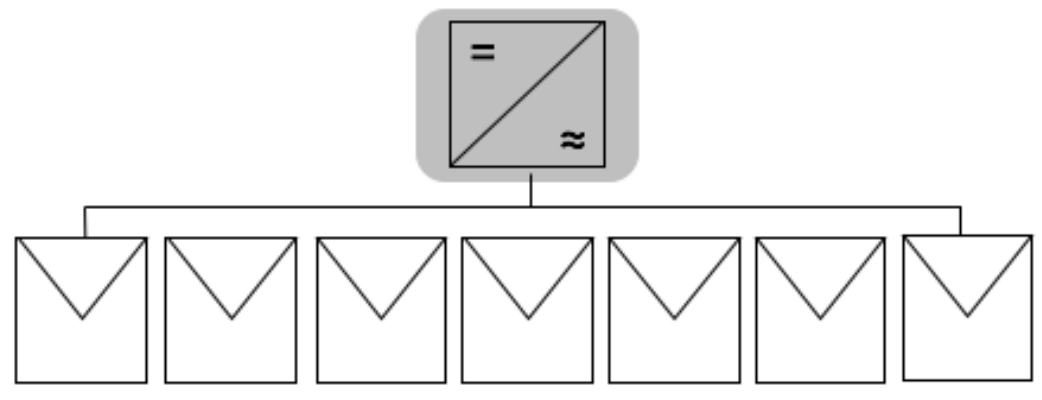

Como se trata de um sistema FV que será utilizado para atividades de ensino, os módulos serão instalados na faixada Sul do edifício e com azimute de $180^{\circ}$ e com inclinação de $10^{\circ}$ devido ao fato de estar direcionada ao Sul, o que indica que inclinações menores levam a uma melhor produtividade. As Figuras 17 e 18 mostram o desenho da disposição dos módulos na planilha “.dwg” com o desenho do projeto do prédio. Sugere-se que a estrutura metálica de inclinação dos módulos possua ajustes e diversos ângulos, de modo que seja possível realizar experimentos quanto a inclinação do sistema fotovoltaico.

Figura 17 Desenho da Instalação 3 na faixada Sul do edifício, Vista Superior (Fonte: o autor).

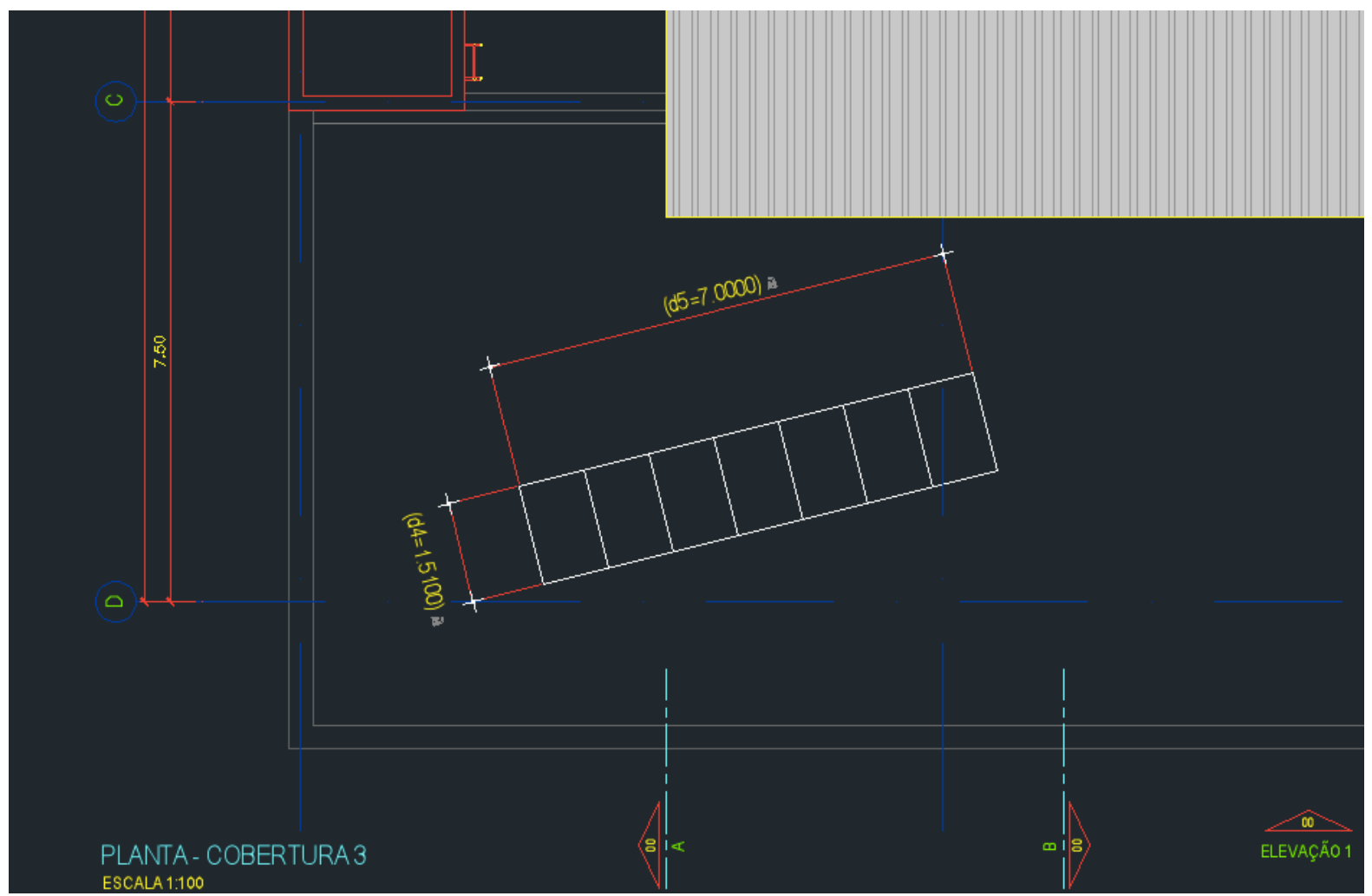


Figura 18: Vista lateral da faixada Sul da cobertura com a Instalação 3 (Fonte: o autor).

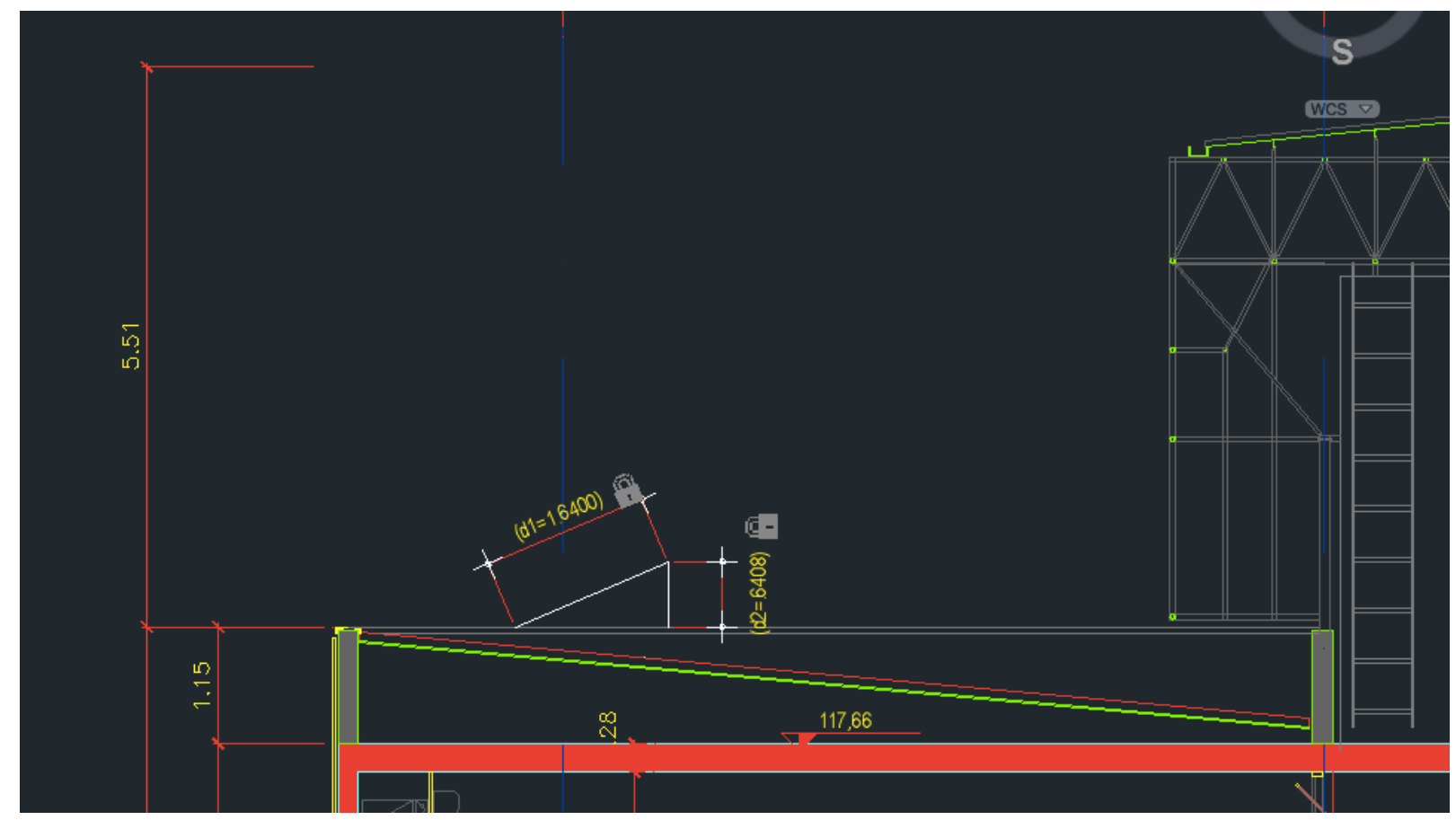

Em razão do pequeno número de módulos fotovoltaicos, optou-se pela orientação de $180^{\circ}$ de azimute para efeitos de estudo de orientação de módulos. A estrutura possui aproximadamente 7 metros de comprimento e largura de 1,64 metros de plano horizontal, estando posicionada a oeste do edifício. A rigorosidade do espaçamento não é grande, uma vez que o espaço não é um fator limitante para este sistema de pequenas dimensões. Quanto a questão estrutural, será necessário a implementação de uma estrutura que suporte a instalação e que permita um livre e seguro acesso aos módulos, tanto por parte de equipe técnica quanto por parte de estudantes.

\section{4. Perdas e Sombreamento}

Com relação as perdas do sistema, foram considerados os mesmos fatores para as três instalações. Consideramos aqui como perdas os seguintes fatores:

- $\quad$ Perdas de irradiação devido ao fator chamado soiling, ou acúmulo de sujeira sobre os módulos. Com base em Miller et al. (2009), definimos assim uma redução de geração de eletricidade anual de 5\% para as Instalações 1 e 3, o que está de acordo com os valores médios encontrados na zona urbana da cidade de Los Angeles nos EUA, sendo esta também uma metrópole litorânea assim como Santos. Já para a Instalação 2, como se trata de módulos posicionados sem nenhuma inclinação, considerou-se um soiling de 7\%. 
- $\quad$ Perdas de corrente contínua (CC): foi considerada uma perda total de 4,44\%, sendo esta subdividida em $2 \%$ de perda por cabeamento; $0,5 \%$ de perda nos diodos e conexões; e por último $2 \%$ de perda por mismatch nos módulos.

- $\quad$ Perdas de corrente alternada (CA): foi considerado uma perda de 1,5\% no cabeamento de corrente alternada.

Quanto às questões de sombreamento, o simulador possui uma calculadora de sombreamento 3D na qual é possível inserir os elementos do edifício e construí-lo com o sistema FV, possibilitando, assim, determinar possíveis sombreamentos. Desta forma, teremos duas situações distintas, uma vez que a Instalação 1 estará na faixada Norte e possui um horizonte sem prédios e com sombreamento praticamente nulo; enquanto que as Instalações 2 e 3 estão na faixada Sul, o que indica menos irradiação durante o dia e sombreamento causado pelo próprio edifício Carvalho de Mendonça.

Figura 19: Vista frontal (faixada Sul) do edifício mostrando a elevação da estrutura metálica (Fonte: Projeto UNIFESP).

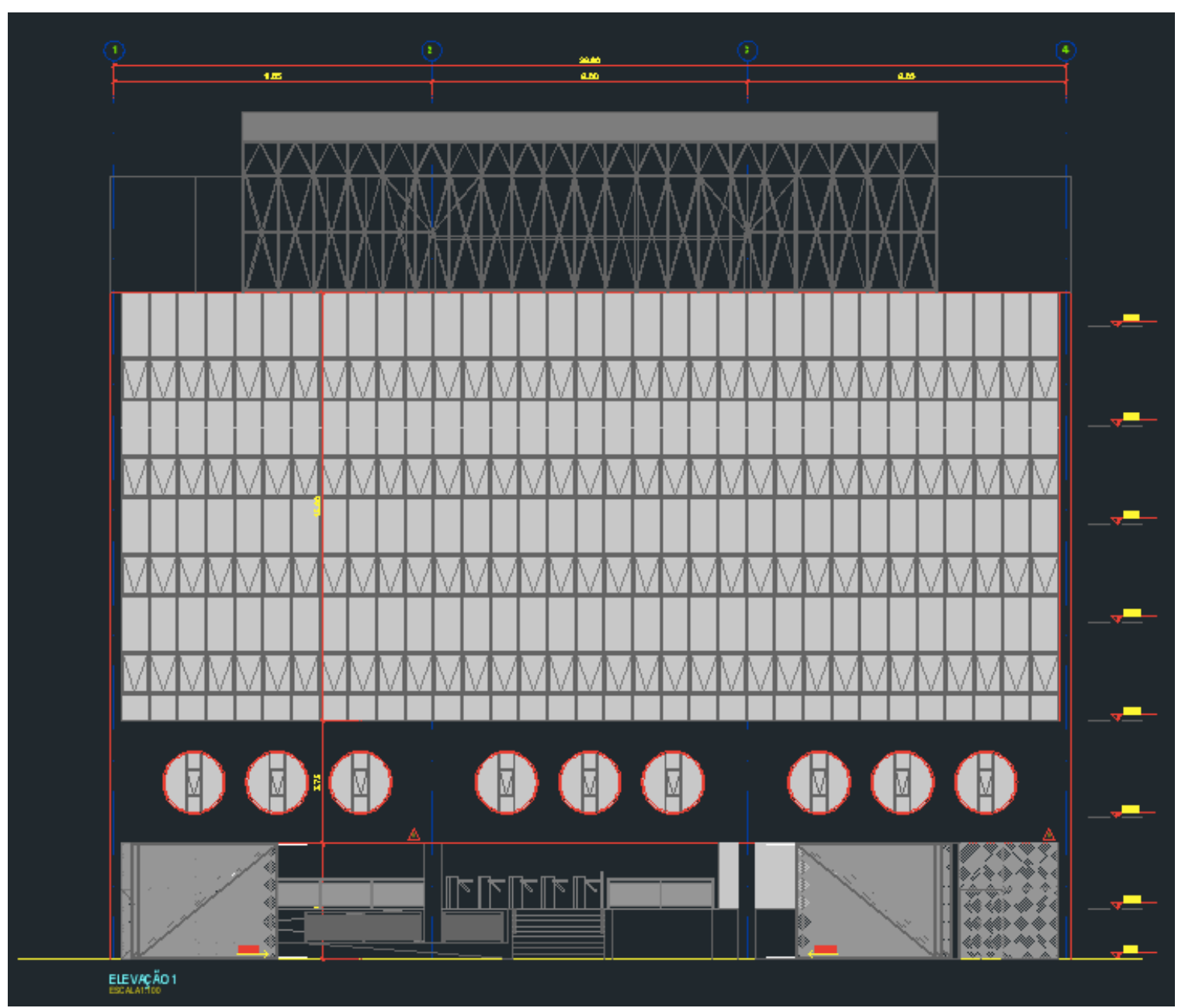


Para a Instalação 1, que conta com dois conjuntos de módulos, foi necessário um espaçamento de 4 metros aproximadamente, devido a utilização do GCR de 0,5 conforme mencionado anteriormente no item 4. 3. Tal fato indica uma condição boa para otimização do espaço. Quanto ao horizonte da faixada, não possui nenhuma edificação que poderia ser considerada fator determinante para sombreamento.

Já para as instalações 2 e 3, a questão é um pouco mais complexa, uma vez que o edifício conta com uma estrutura metálica que se eleva na parte central em cerca de 5 metros, proporcionando sombreamento na faixada sul da cobertura. A Figura 19 apresenta esta estrutura no projeto do edifício.

\section{5. Parâmetros Financeiros}

Para realizar a análise financeira, será utilizado o parâmetro chamado Levelized Cost of Electricity (LCOE), que se refere ao custo por $\mathrm{kWh}$ incluindo todos os custos de investimento, de operação e de manutenção ao longo do da vida útil do sistema, incluindo ainda o custo de equipamentos substituídos. A vantagem da utilização deste método está no fato de permitir a comparação com diferentes plantas de geração de eletricidade (EPIA, 2011). Abaixo segue a equação do LCOE de acordo com o que foi colocado por Nakabayashi, 2015:

$$
L C O E=\frac{\text { Custos ao longo da vida útil }}{\text { Energia gerada ao longo da vida útil }}=\sum_{t=0}^{T} \frac{\frac{C_{t}}{(1+r)^{t}}}{\frac{E_{t}}{(1+r)^{t}}}
$$

onde $\mathrm{C}_{\mathrm{t}}$ e $\mathrm{E}_{\mathrm{t}}$ representam os custos e a energia gerada no período $\mathrm{t}$, respectivamente, e $\mathrm{r}$ a taxa de desconto. Desta forma, alguns fatores são necessários para que o SAM consiga calcular o LCOE. Os dados inseridos no simulador estão de acordo com a Tabela 10 a seguir.

Tabela 10: Dados financeiros adicionados ao simulador.

\begin{tabular}{lc}
\hline \multicolumn{2}{c}{ Parâmetros Financeiros } \\
\hline Custo $\$ / \mathrm{Wp}$ & 5,50 \\
Período de análise & 25 anos \\
Inflação & $6 \%$ \\
Taxa Interna de Retorno & $10 \%$ \\
Custo O\&M & $1 \%$ a.a. \\
\hline
\end{tabular}


O primeiro fator é o custo em $\mathrm{R} \$ / \mathrm{Wp}$, ou seja, o custo do sistema com relação a potência instalada. $\mathrm{O}$ valor de 5,5 R $\$ / \mathrm{Wp}$ foi estimado de acordo com documento da ABINEE (2015) que realiza um estudo sobre a viabilidade econômica da microgeração fotovoltaica no Brasil, assim como por consulta de preços dos equipamentos em lojas especializadas no país. Com relação aos outros dados, baseia-se no principio de que a vida-útil do sistema fotovoltaico é de 25 anos, com um custo de operação e manutenção (O\&M) de 1\% ao ano do custo total do sistema FV, dados estes recomendados para projetos de acordo com PINHO et al. (2014).

Para determinar a inflação, optou-se por um valor de 6\% ao ano, o que indica bem o cenário inflacionário do Brasil nos próximos anos. Como parâmetro para que o sistema calcule o Valor Presente Líquido (VPL) para determinar o LCOE definimos a Taxa Interna de Retorno (TIR) como sendo de $10 \%$, uma vez que se trata de um sistema com alta potência instalada, reduzindo assim os custos dos equipamentos.

Conforme mencionado anteriormente, a análise financeira dar-se-á somente na Instalação 1, uma vez que as outras 2 serão apenas ferramentas de estudo e atividades acadêmicas da UNIFESP. 


\section{RESULTADOS}

Serão apresentados a seguir os resultados das simulações realizadas para as 3 instalações do edifício. Ressalta-se que o cálculo de LCOE será apenas sobre a Instalação 1.

\section{1. Instalação 1}

Com relação aos dados de irradiação, a Figura 20 mostra um histograma de ocorrência dos dados de irradiação global horizontal (GHI). Com este gráfico, observa-se a frequência de ocorrência dos valores de GHI durante um ano de dados coletados. Nota-se também que tal gráfico indica que a ocorrência de altas porcentagens em valores abaixo de $100 \mathrm{~W} / \mathrm{m}^{2}$ pode mostrar como a nebulosidade ou outros fatores de atenuação afetam a distribuição dos dados ao longo do ano. Vale ressaltar também sobre o local da estação meteorológica de Moela, que se situa em um local que pode levar a falhas de coleta de irradiação devido ao sombreamento da geologia local da ilha.

Figura 20: Histograma da distribuição dos dados de irradiação global horizontal (GHI) (Fonte: próprio Autor).

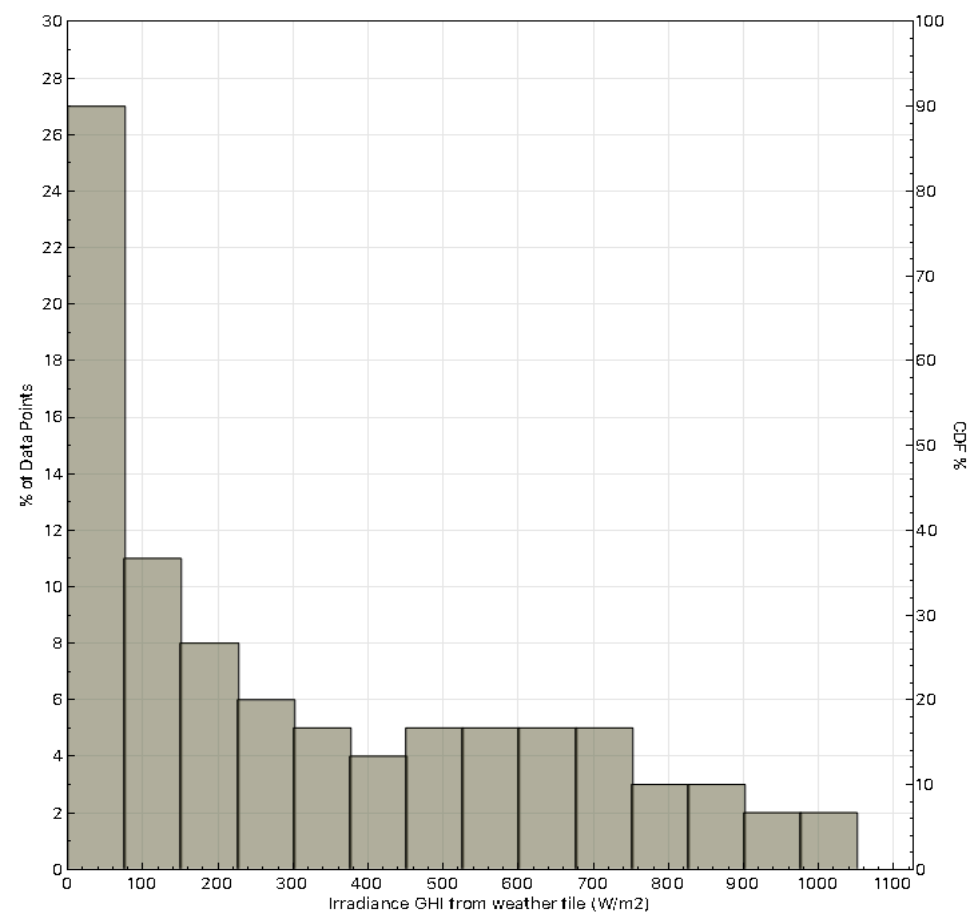

Para entender como é o perfil da distribuição da irradiação ao longo do ano, o simulador gerou um gráfico com esta distribuição ao longo dos meses do ano. Desta forma, a 
Figura 21 mostra como os valores das médias horárias da GHI em cada mês. Tais gráficos são essenciais para compreender o comportamento da GHI ao longo dos meses durante o ano referente a coleta de dados.

Figura 21: Médias horárias de GHI dos dias separado pelos meses do ano (Fonte: próprio Autor).
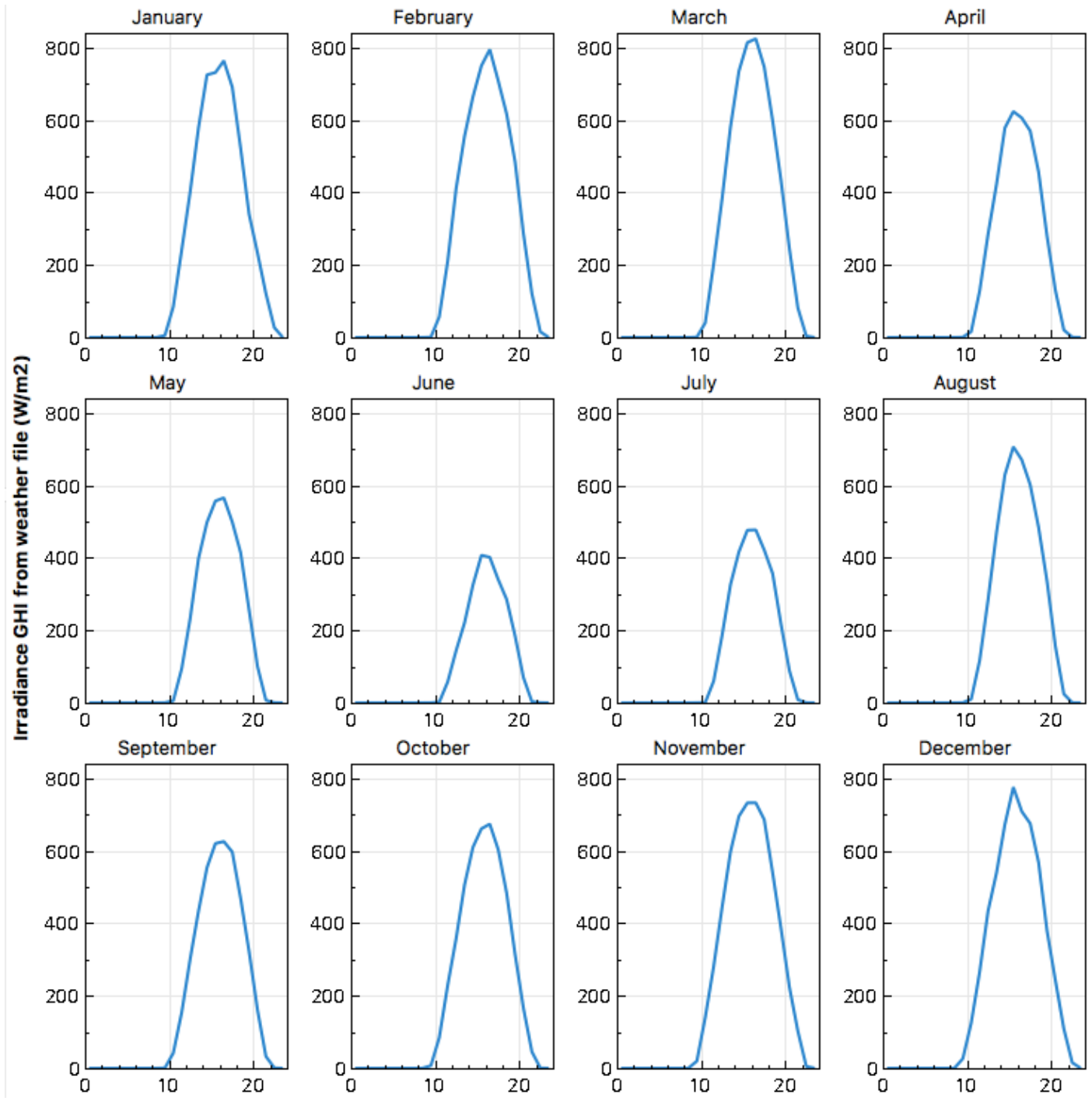

A Figura 22 relaciona a irradiação solar incidente nos painéis fotovoltaicos e a energia gerada pelo sistema, sendo que a linha laranja representa a potência da planta FV e a azul representa a GHI. Este comportamento é muito importante para analisar a sazonalidade da geração de energia. 
Figura 22: Gráfico comparativo entre os valores de GHI (linha azul) e da potência gerada em kW (linha laranja) para a Instalação 1 (Fonte: próprio Autor).
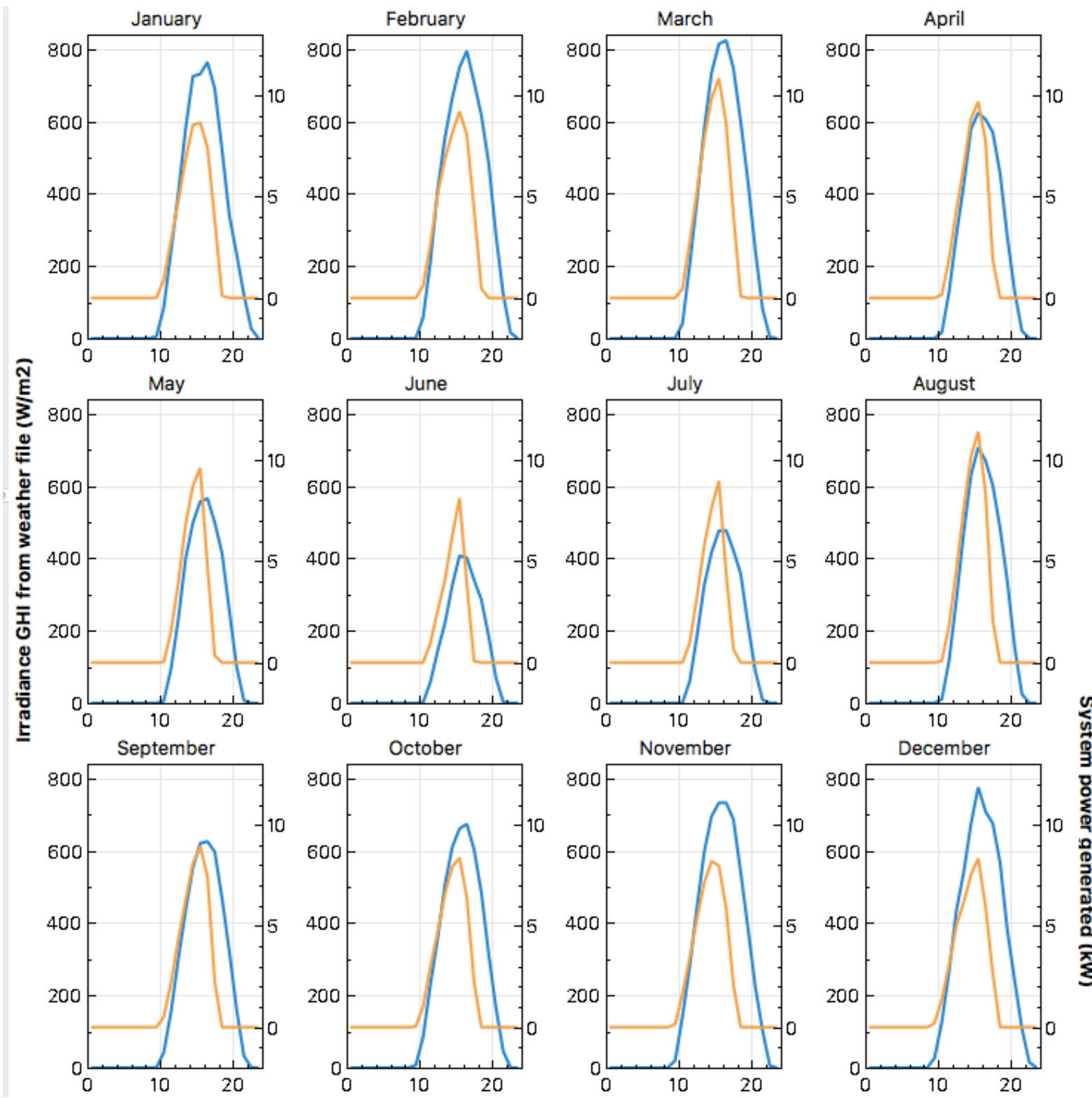

Desta forma, observa-se uma característica bastante interessante da região de Santos nos meses de inverno. Com exceção do mês de junho, temos um período de inverno com índices de irradiação que levam a uma baixa variabilidade de geração de eletricidade ao longo do ano. A Figura 23 mostra dois mapas de calor que auxiliam na constatação deste padrão.

Sendo assim, confirma-se o que é mostrado na Figura 22, onde temos meses de inverno com altos valores de geração. Tal fato pode ser explicado devido ao período de seca no Brasil, ou seja, período onde as chuvas são reduzidas e consequentemente a nebulosidade. 
De modo oposto, as estações chuvosas, principalmente o verão, apresentam altos índices pluviométricos levando assim a uma redução de geração.

Outro fator a ser considerado são as temperaturas elevadas durante o período de verão que reduzem a eficiência do sistema fotovoltaico uma vez que o desempenho das células fotovoltaicas está intrinsecamente ligado a temperatura do módulo.

Figura 23: Mapa de calor indicando a GHI a esquerda e a Geração de Energia a direita ao longo das horas do dia (Fonte: próprio Autor).
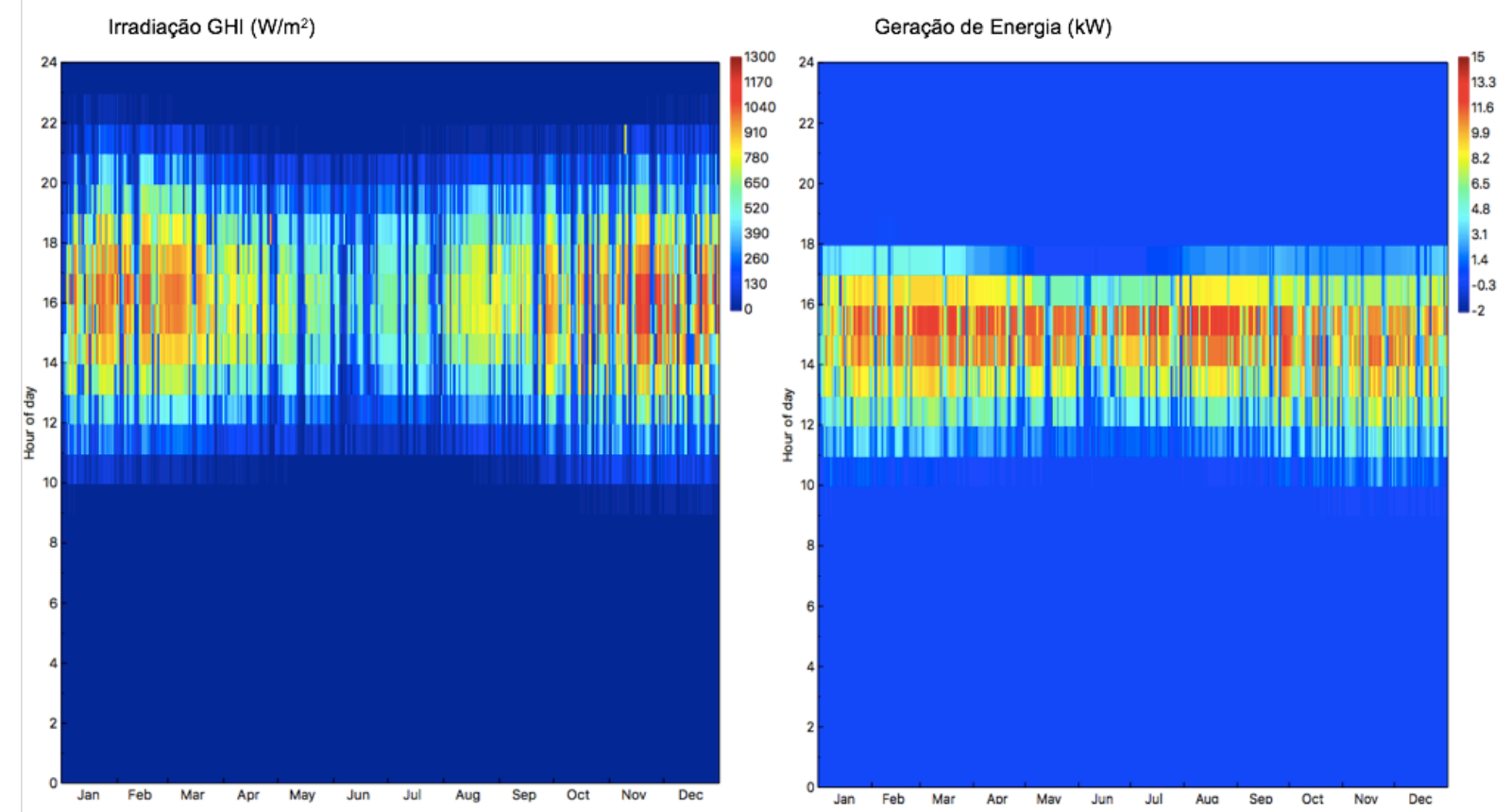

Para definir a geração de eletricidade $(\mathrm{kWh})$ é necessário realizar a integração da curva laranja apresentada na Figura 22, levando ao gráfico de mensal encontrado na Figura 24. Este gráfico nos mostra o que os piores meses para a geração de energia elétrica é junho e julho, ao passo que março e agosto são os meses com maior geração.

O verão na região de Santos é uma estação bastante chuvosa, o que prejudica a incidência de irradiação. De modo contrário, o final do inverno (agosto/setembro) se caracteriza como um período com céu claro e com baixa nebulosidade, sendo este um fator positivo para geração fotovoltaica.

Desta forma, de acordo com a simulação, a planta apresentou uma geração no primeiro ano de uso de $14.912 \mathrm{kWh}$ com um fator de capacidade de 10,4\% e um Performance Ratio (PR) de 0,70. Este último se mostrou baixo perto do que se encontra em plantas em operação (Oliveira et al., 2001; Reich et al., 2012; Pinho et al., 2014) o que pode ser justificado pelo fato da orientação dos módulos que não estão com azimute igual a zero, assim como perdas 
por fatores de temperatura do módulo. Já o Energy Yield foi de $911 \mathrm{kWh} / \mathrm{kW}$ instalado, sendo este valor bem próximo do que é mostrado em Pereira et al. (2017).

Figura 24: Geração mensal de eletricidade da planta FV da Instalação 1 (Fonte: próprio Autor).

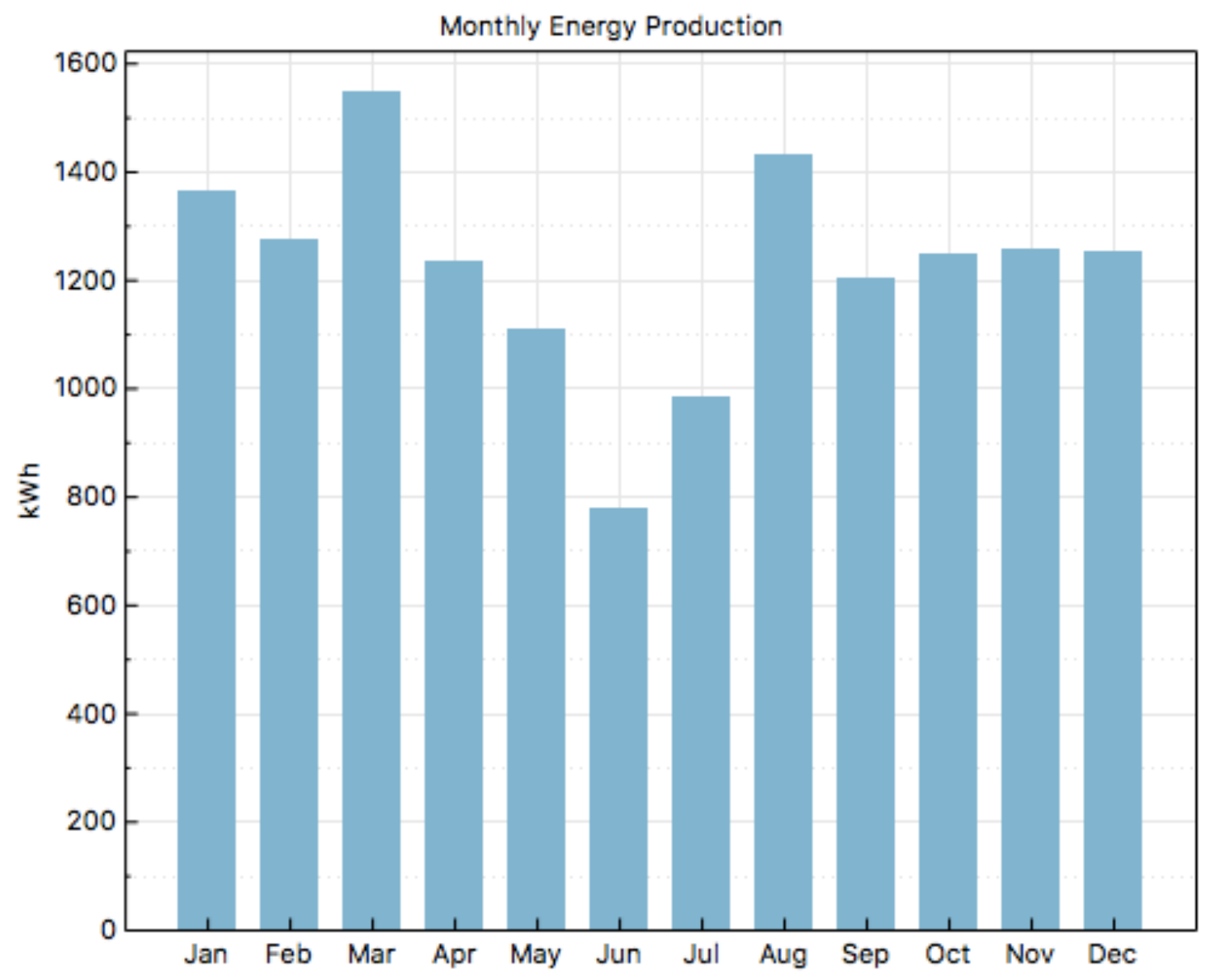

Com relação ao PR, temos ainda as perdas do sistema que contribuem para a redução deste valor. Podemos constatar que as altas temperaturas são indicadas como o fator de maior perda de desempenho do sistema, chegando na casa dos $15 \%$ no ano. As células fotovoltaicas atingem temperaturas que provocam uma redução de $0,424 \% /{ }^{\circ} \mathrm{C}$ e $1,079 \mathrm{~W} /{ }^{\circ} \mathrm{C}$ (características do módulo), ou seja, forte redução de eficiência e potência quando se passa das temperaturas de referência. Isto pode ser evidenciado na Figura 25, que relaciona a temperatura da célula (curva laranja), temperatura ambiente (curva vermelha) e a eficiência do módulo (curva azul). Desta forma fica claro como os picos de temperatura da célula durante o dia levam a queda da eficiência de conversão da energia solar em eletricidade. 
Figura 25: Gráfico comparativo entre temperatura da célula (curva laranja), temperatura ambiente (curva vermelha) e a eficiência do módulo (curva azul) da Instalação 1 (Fonte: próprio Autor).
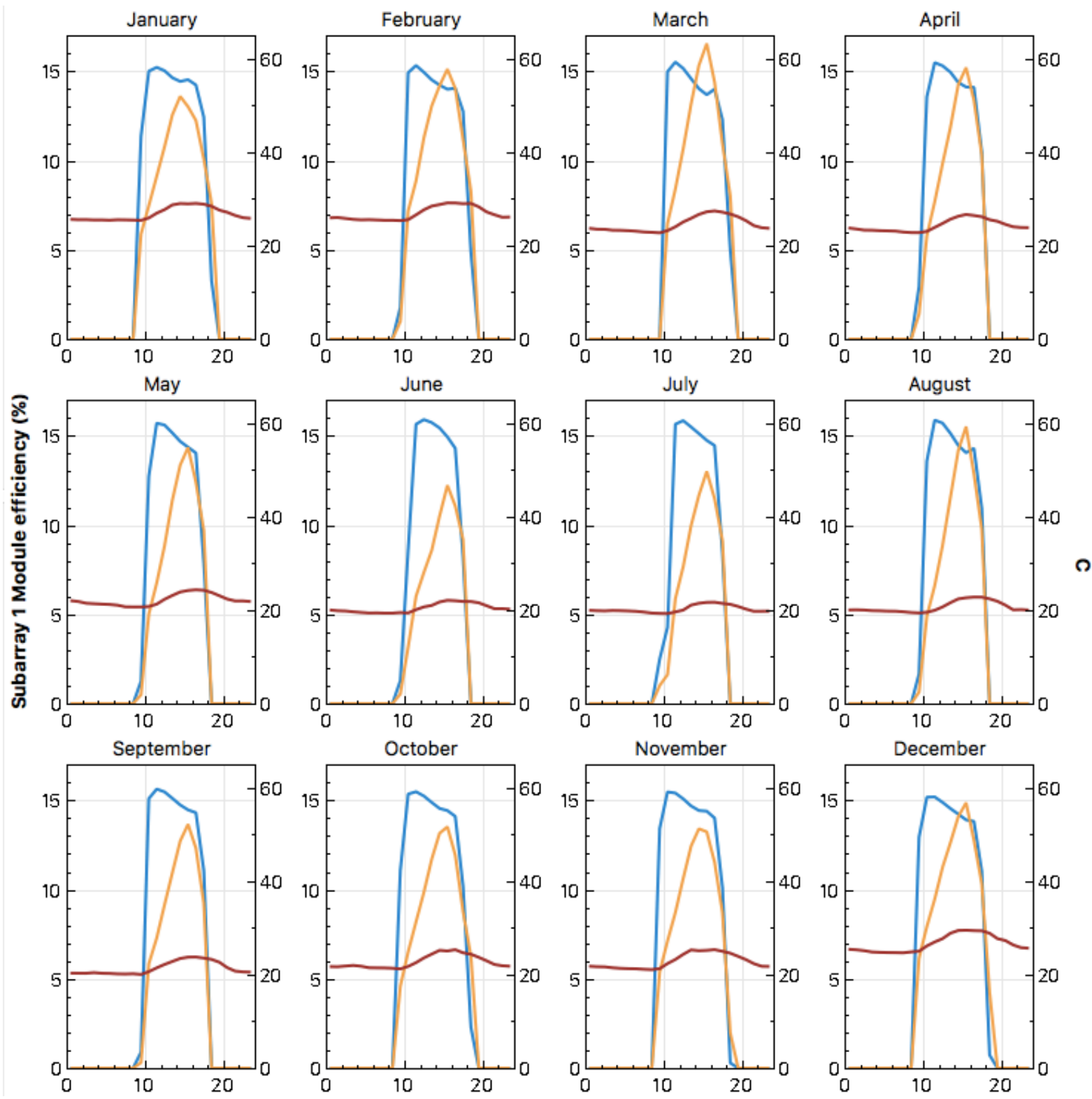

A Figura 26 nos mostra um resumo das perdas do sistema. Outras perdas estão relacionadas às questões elétricas, como cabeamento e vale destacar a perda de eficiência do inversor, que atinge a casa dos 2,5\%. Temos ainda as perdas por soiling que são de $5 \%$ uma vez que Santos é uma cidade com bastante particulado devido aos caminhões, ao porto e ao fato de ser uma cidade litorânea. Porém, ressalta-se que este foi um valor escolhido com base na literatura, conforme comentado anteriormente, e deve ser estudado e analisado durante a vida útil do equipamento para chegar em valores mais exatos. 
Figura 26: Porcentagem de cada tipo de perda do sistema FV da Instalação 1 (Fonte: próprio Autor).

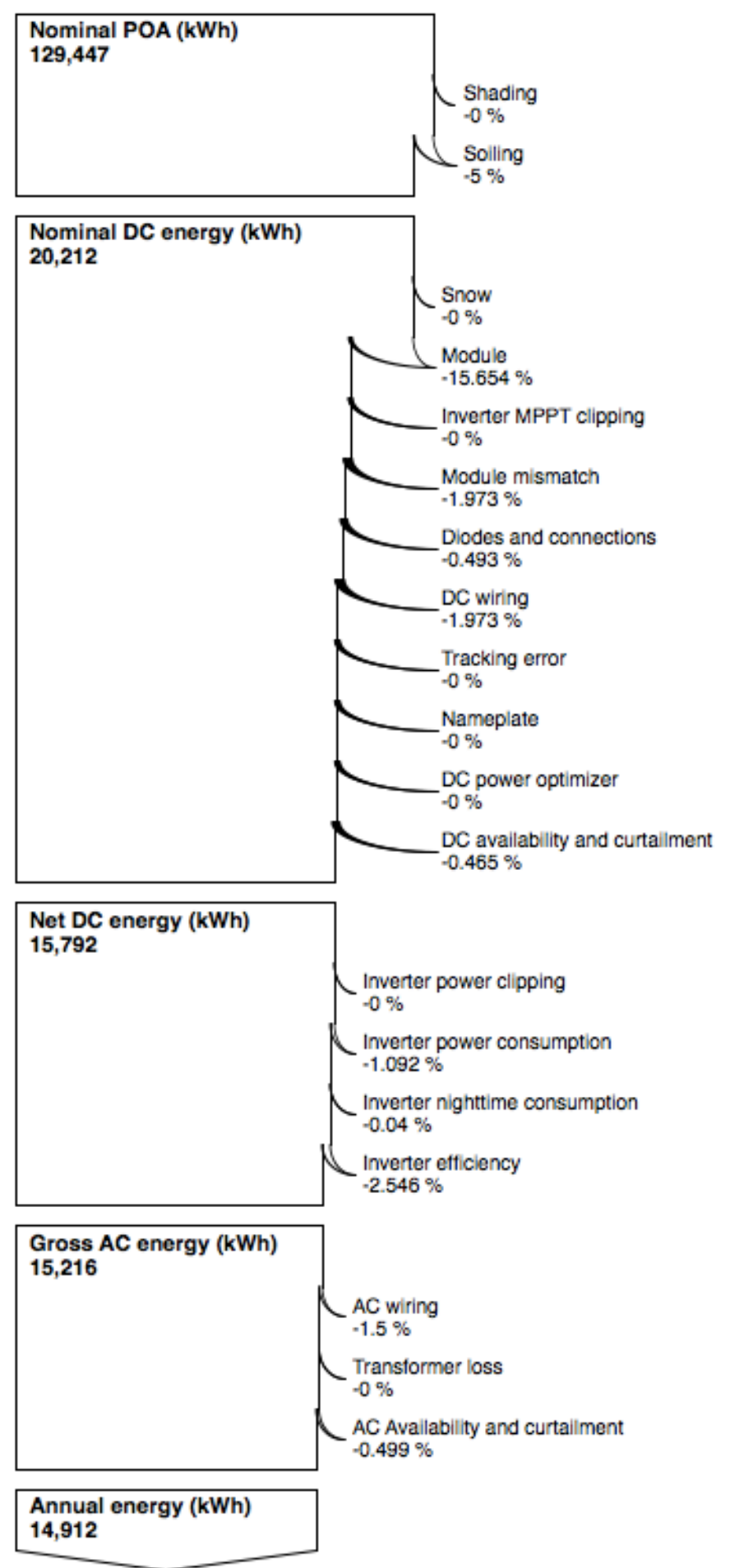

Outra questão relacionada a perda é o sombreamento causado pela coluna da frente (coluna 1) sobre a coluna de trás (coluna 2), conforme mostrado na metodologia. O simulador possui uma ferramenta 3D para análise de sombreamento, auxiliando assim a determinar a porcentagem sombreada dos módulos. Porém, se trata de uma ferramenta de baixa precisão, o que indicam dados aceitáveis, sendo assim necessário um estudo mais aprofundado das 
questões de sombreamento de acordo com a região no entorno do edifício, assim como do posicionamento do Sol. De qualquer modo, a Figura 27 mostra um comparativo da irradiação mensal total no plano dos módulos (plano inclinado - POA) comparada com seu nível após as reduções de soiling e sombreamento. Porém, ressalta-se que o sombreamento externo é praticamente nulo uma vez que existem poucos edifícios na região que podem levar a um grande sombreamento da planta.

Figura 27: Comparativo dos níveis mensais de irradiação total no plano dos módulos antes e após as perdas por sombreamento externo e soiling (Fonte: próprio Autor).

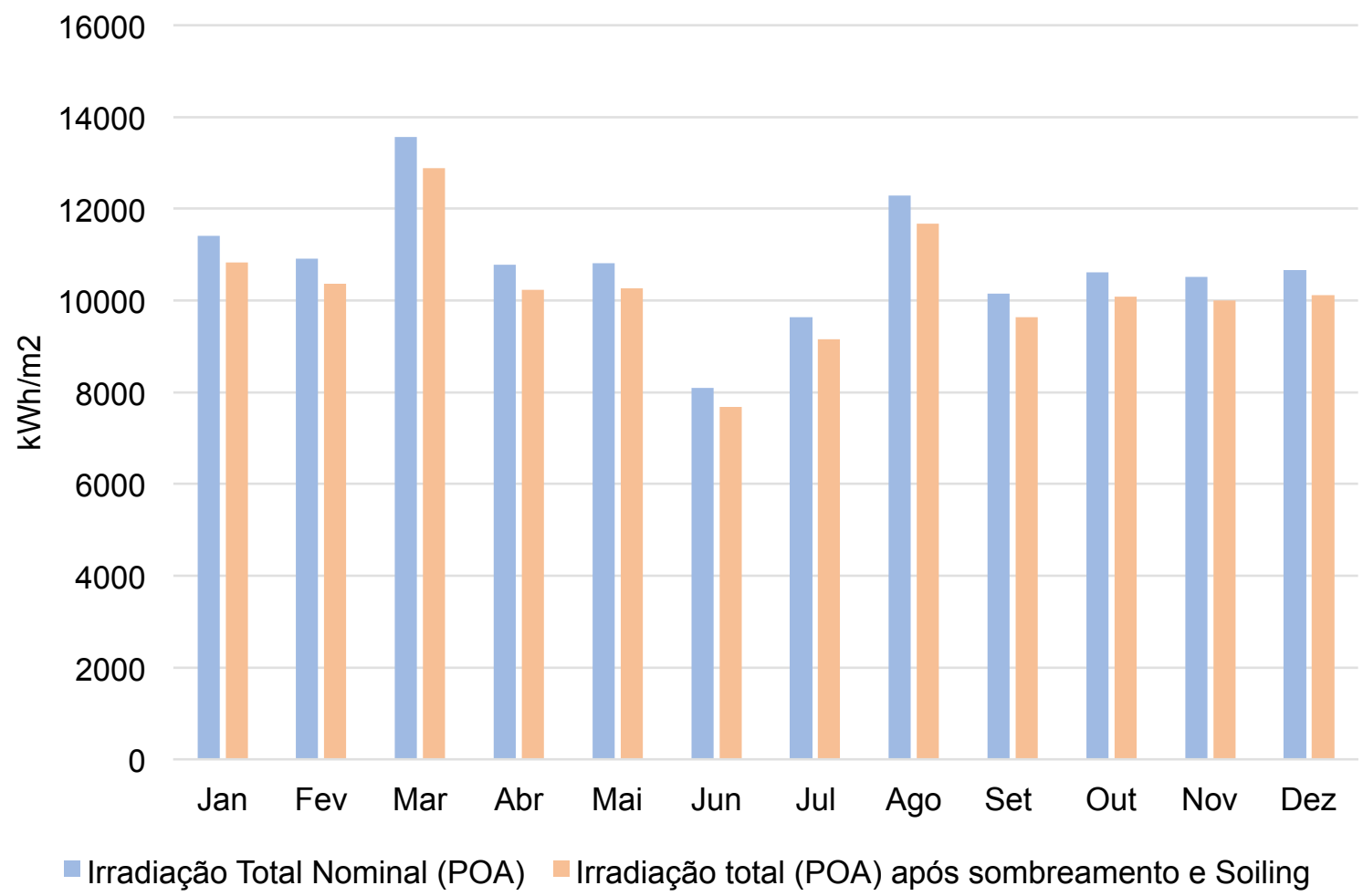

Por outro lado, tem-se as questões do sombreamento nos módulos da coluna de trás causado pelos próprios módulos que estão na coluna da frente. Tais resultados calculados e estimados pelo programa não estão bem claros e aparentam possuir erros e se mostram resultados grosseiros. Este sombreamento causa perdas nos módulos devido às questões elétricas e no efeito causado aos by-pass das células fotovoltaicas que compõem o módulo, explicado por Deline (2010) e testado e experimentado por outros (Lu et al., 2013; Fialho et al., 2013). Todos estes fatores ajudam a compor as perdas de aproximadamente 15,5\% indicada na Figura 26. 
Por último, tem-se a questão do Levelized Cost of Electricity (LCOE) obtido na planta. Este fator nada mais é do que um índice que indica os custos totais do sistema divididos pela energia gerada. Ou seja, quanto menor o valor desta taxa, melhor será o investimento uma vez que os custos do sistema serão bem menores que os benefícios econômicos que o sistema FV trará ao investidor.

Desta forma, o resultado obtido para o LCOE da planta foi de 0,4376 R $\$ / \mathrm{kWh}$. Este método é bastante utilizado em análises comparativas entre diversas fontes de energia. De qualquer forma, tal valor se apresentou bem alto quando comparado com os resultados obtidos no Nordeste brasileiro por Alves et al. (2015). Muitos fatores levam a esta diferença, como por exemplo irradiação menor em Santos.

Uma forma de se analisar a viabilidade pelo LCOE é comparando o valor deste com o da tarifa de energia elétrica pago pelo consumidor. Desta forma, consultando o histórico do pagamento de contas de energia da UNIFESP cedidas pelo departamento responsável da instituição, observa-se que o valor médio pago no ano de 2017 foi de $0,7040 \mathrm{R} \$ / \mathrm{kWh}$. Sendo assim, observa-se que diante do cenário atual de bandeira tarifária vermelha devido a situação ruim dos reservatórios (ONS, 2017), o investimento em uma planta fotovoltaica por parte da universidade seria uma boa alternativa, uma vez que o custo por kWh pago na planta é mais baixo que o valor pago para distribuidora de energia local. Ressalta-se que esta é uma análise financeira pouco aprofundada, sendo necessário o complemento de outros métodos. Recomenda-se futuros trabalhos com uma relação mais precisa de fluxo de caixa, Valor Presente Líquido (VPL), Taxa Interna de Retorno (TIR) e Payback para uma melhor avaliação do projeto.

Ainda, não foi objetivo deste trabalho analisar custos de adaptação do edifício para instalação da planta, como por exemplo da superfície de sustentação, assim como de equipamentos de segurança e infraestrutura para acesso ao sistema fotovoltaico.

\section{2. Instalação 2}

Conforme colocado anteriormente, esta planta será utilizada em atividades acadêmicas de ensino e estudos de orientação em Trabalhos de Conclusão de Curso. Ela será relativamente móvel com o intuito de permitir avaliação de desempenho do sistema em função da geometria de iluminação. No entanto, como ela está inicialmente direcionada para o Sul, espera-se uma geração menor de eletricidade, principalmente no inverno. Desta forma, a 
Figura 28 apresenta o gráfico da média horária mensal da irradiação global GHI em azul e a curva de potência do sistema em $\mathrm{kW}$ na linha laranja.

Fica claro diante da figura como a orientação dos módulos afeta a geração do sistema. Observa-se que nos meses de verão, a produção é considerável, porém no resto do ano a geração reduz drasticamente. Isso se deve ao fato de que no verão o Sol está mais a pico, o que possibilita maior tempo de incidência de radiação solar na faixada Sul do edifício; e de modo contrário, no inverno o Sol está posicionado sobre o hemisfério Norte e com menor altitude solar, acarretando menor incidência nesta parte do edifício.

Figura 28: Gráfico comparativo entre os valores de GHI (linha azul) e da potência gerada em kW (linha laranja) para a Instalação 2 (Fonte: próprio Autor).
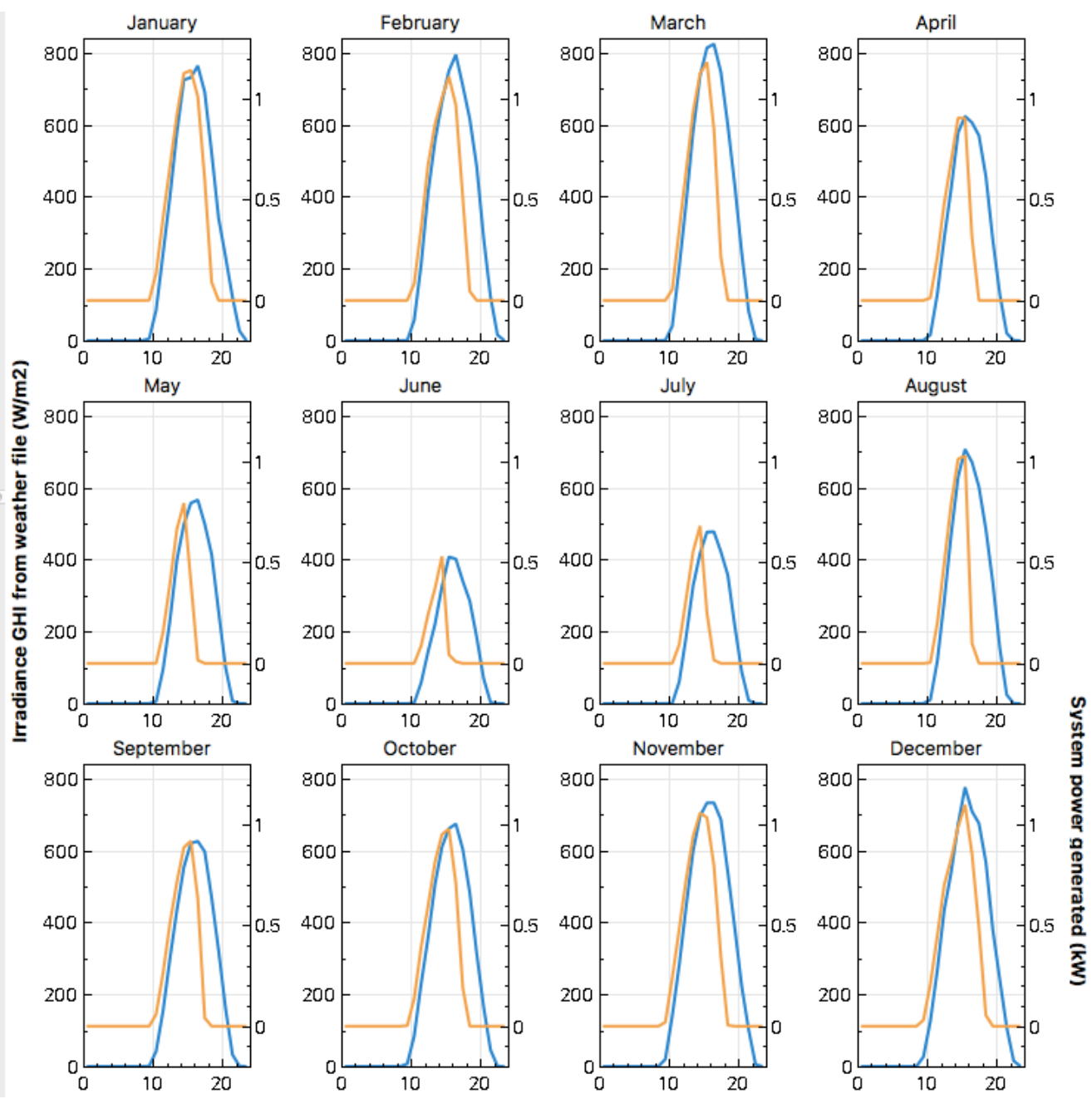

Outro fator que é representativo é o fato dos módulos não possuírem inclinação. Em teoria, quando direcionados para o Sul, quanto menor a inclinação dos módulos maior seria o tempo de incidência de Sol. Porém, a inclinação nula permite um maior acumulo de sujeira 
(soiling). Desta forma, este sistema terá papel importante nos estudos futuros por parte dos laboratórios da universidade.

A partir deste gráfico, integrando a curva laranja tem-se a geração mensal de eletricidade em kWh apresentada na Figura 29. A geração total no primeiro ano foi de 1.538 $\mathrm{kWh}$, possuindo um fator de capacidade de 7,7\% e um PR de 0,63. Estes dados estão dentro do que se era esperado para esta instalação, uma vez que estão direcionados para Sul e com zero inclinação, o que aumenta soiling. Fica claro como o inverno prejudica a geração, possuindo uma queda brusca, principalmente quando o Sol começa se distanciar do hemisfério Sul nos meses de abril, maio, junho e julho.

Figura 29: Geração mensal de eletricidade da planta FV da Instalação 2 (Fonte: próprio Autor).

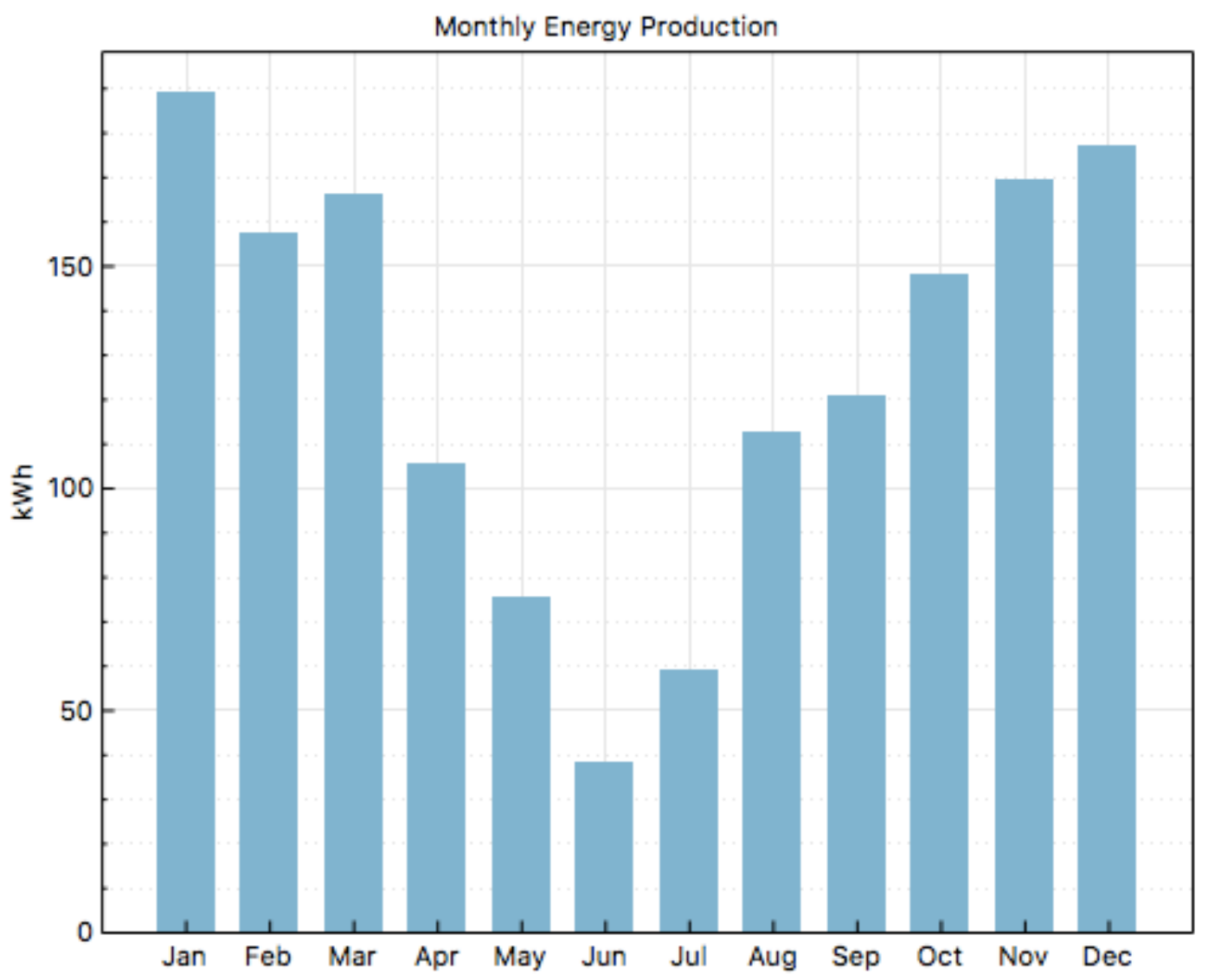

As perdas que levam a redução do PR são descritas na Figura 30, contendo todas as porcentagens de cada fator. Destaque para a perda dos módulos, que atingem valores altos na casa dos $18 \%$ e se devem tanto por parte dos efeitos de sombreamento (Deline, 2010) devido à geometria de instalação do sistema e também devido aos coeficientes de perda de eficiência 
e potência (respectivamente, $0,542 \% /{ }^{\circ} \mathrm{C}$ e $1,236 \mathrm{~W} /{ }^{\circ} \mathrm{C}$ ). Estas perdas por temperatura são menos acentuadas no inverno devido aos menores índices de irradiação na faixada Sul.

Figura 30: Porcentagem de cada tipo de perda do sistema FV da Instalação 2 (Fonte: próprio Autor).
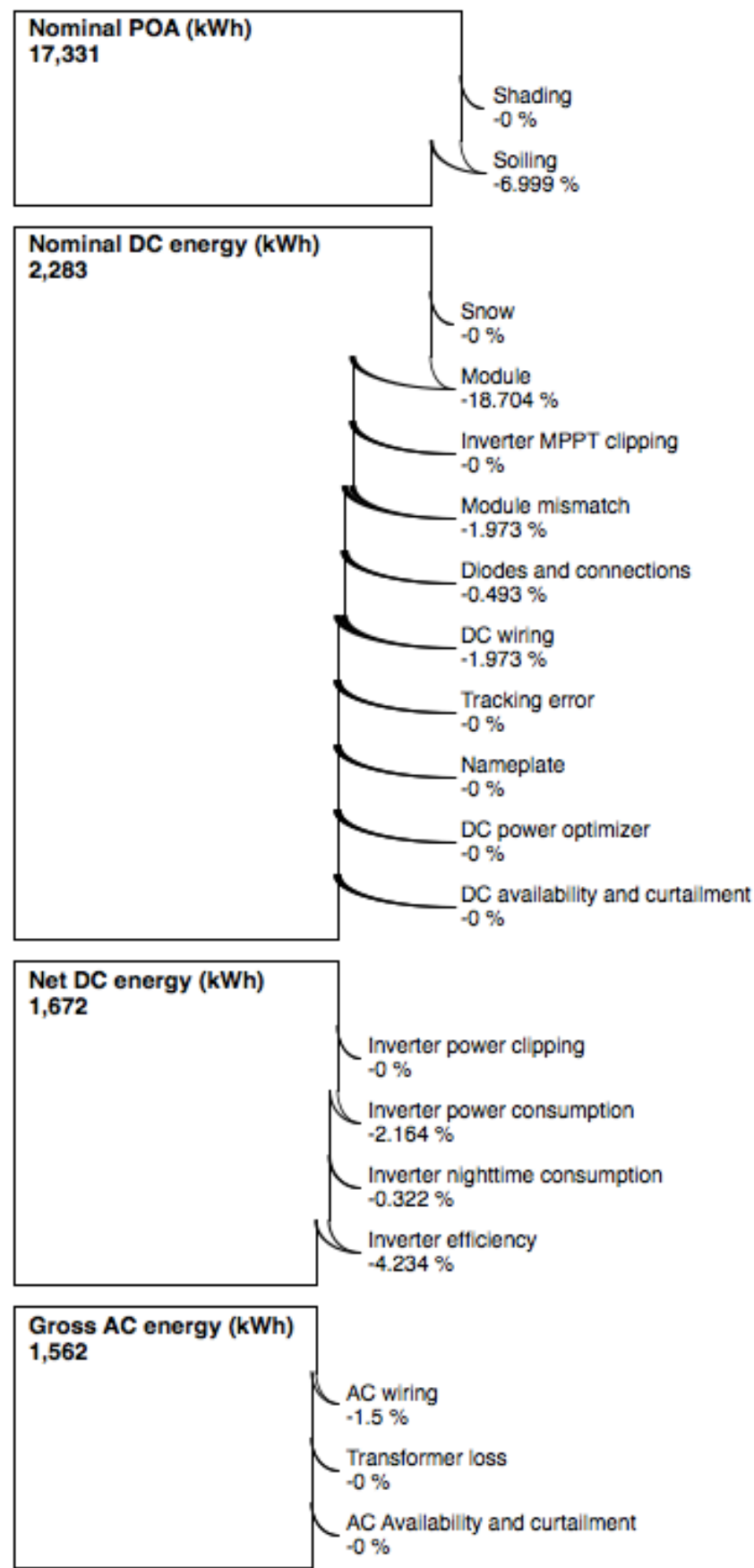

Annual energy (kWh) 1,538 
O Energy Yield da planta foi de $674 \mathrm{kWh} / \mathrm{kW}$, número muito abaixo do que obtido na Instalação 1. Isso se deve em grande parte a três fatores: orientação dos módulos com azimute de 166 graus, inclinação nula que leva ao maior acúmulo de sujeira e menor índice de irradiação, e por último à tecnologia dos módulos (CIGS) que no geral possui menor eficiência.

\section{3. Instalação 3}

Da mesma forma que na Instalação 2, esta planta será utilizada com intuito de capacitação de estudantes e investigação quanto orientação e inclinação dos módulos. Desta forma, a Figura 31 apresenta o gráfico da média horária mensal da irradiação global GHI em azul e a curva de potência do sistema em kW na linha laranja.

Figura 31: Gráfico comparativo entre os valores de GHI (linha azul) e da potência gerada em kW (linha laranja) para a Instalação 3 (Fonte: próprio Autor).
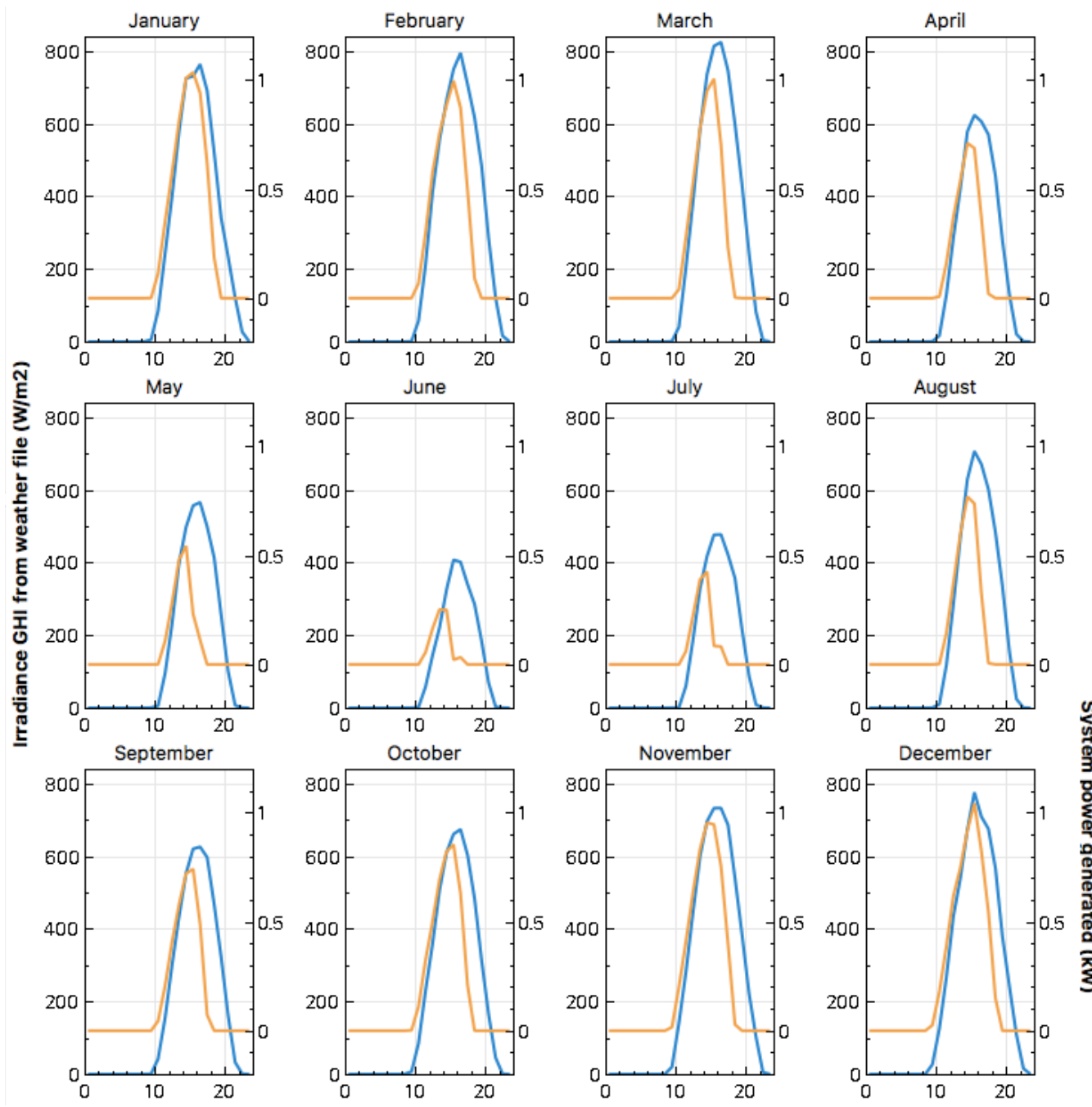
Fica claro diante da figura como a orientação dos módulos afeta a geração do sistema. Observa-se que nos meses de verão, a produção é considerável, porém no resto do ano a geração reduz drasticamente. Isso se deve ao fato de que no verão o Sol está elevado no ceú e o tempo entre o nascer e por de Sol é mais longo na faixada Sul do edifício; e de modo contrário, no inverno o Sol está mais distante do Hemisfério Sul e também mais baixo, acarretando menor incidência nesta parte do edifício.

Integrando a curva laranja da Figura 31, tem-se a geração mensal de eletricidade em kWh apresentada na Figura 32. De acordo com a simulação, a geração anual de energia no primeiro ano de uso foi de $1.295 \mathrm{kWh}$ com um PR de 0,69 e um fator de capacidade de 7,8\%. Novamente foi obtido um PR baixo, porém, considerando o posicionamento da planta com azimute de 180 graus, o valor indica uma boa performance. O que chama a atenção dos resultados é o fator de capacidade, uma vez que este é extremamente baixo e muito disso se deve ao fato da baixíssima geração durante grande parte do ano, deixando o sistema praticamente inoperante em grande parte do tempo.

Figura 32: Geração mensal de eletricidade da planta FV da Instalação 3 (Fonte: próprio Autor).

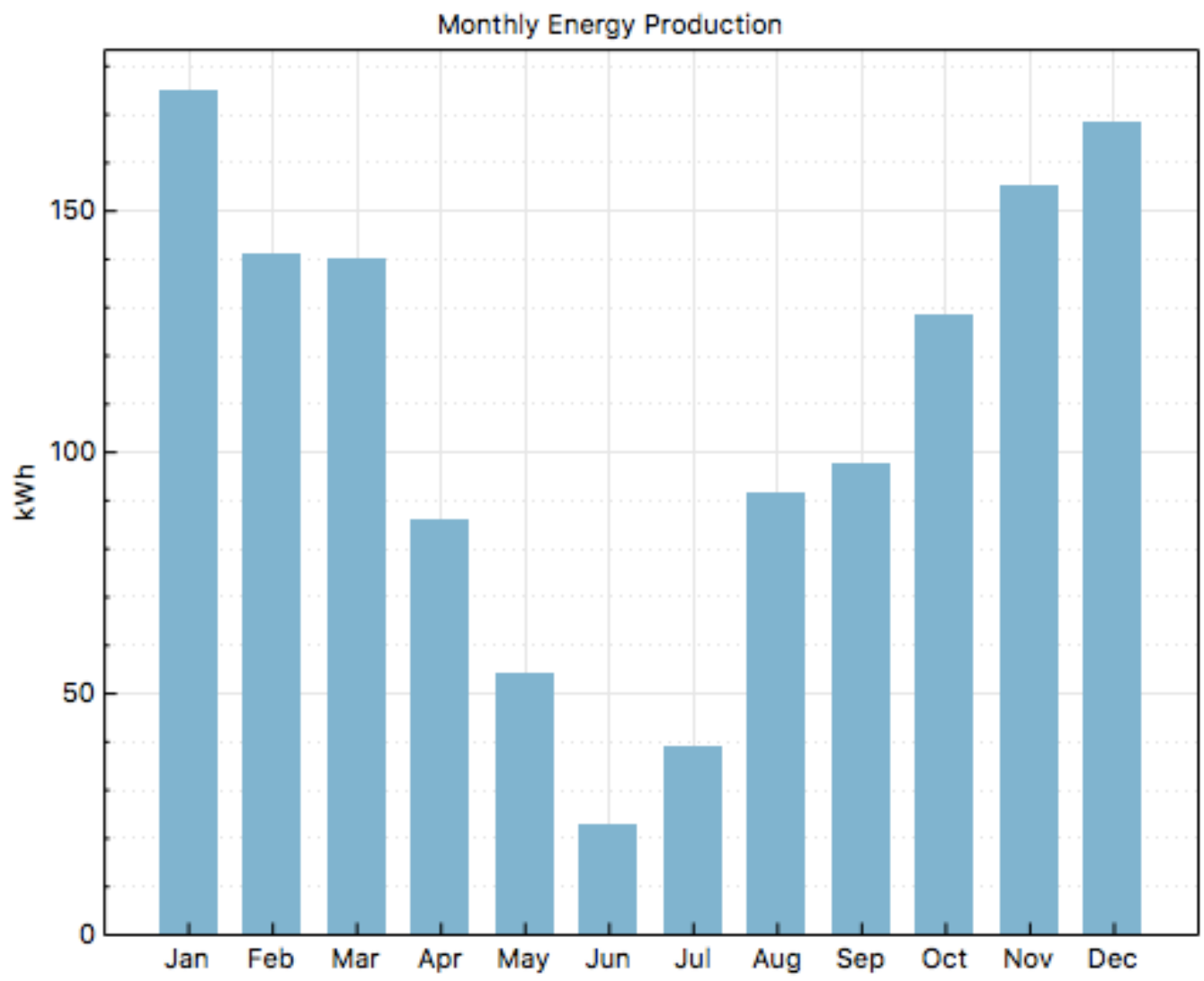


As perdas que levam a redução do PR estão indicadas na Figura 33. Percebe-se que existe grande perda dos módulos, assim como nas outas instalações, porém de forma menos acentuada. Isto pode ser explicado pelas baixas temperaturas que as células atingem menores temperaturas durante o inverno devido a menor incidência direta de irradiação. De qualquer modo, os módulos apresentam coeficientes de redução menores que os da Instalação 1 e 2 $\left(0,377 \% /{ }^{\circ} \mathrm{C}\right.$ e $\left.1,018 \mathrm{~W} /{ }^{\circ} \mathrm{C}\right)$, o que ajudou também esta menor perda e consequentemente um PR maior que em 2.

Figura 33: Porcentagem de cada tipo de perda do sistema FV da Instalação 3 (Fonte: próprio Autor).

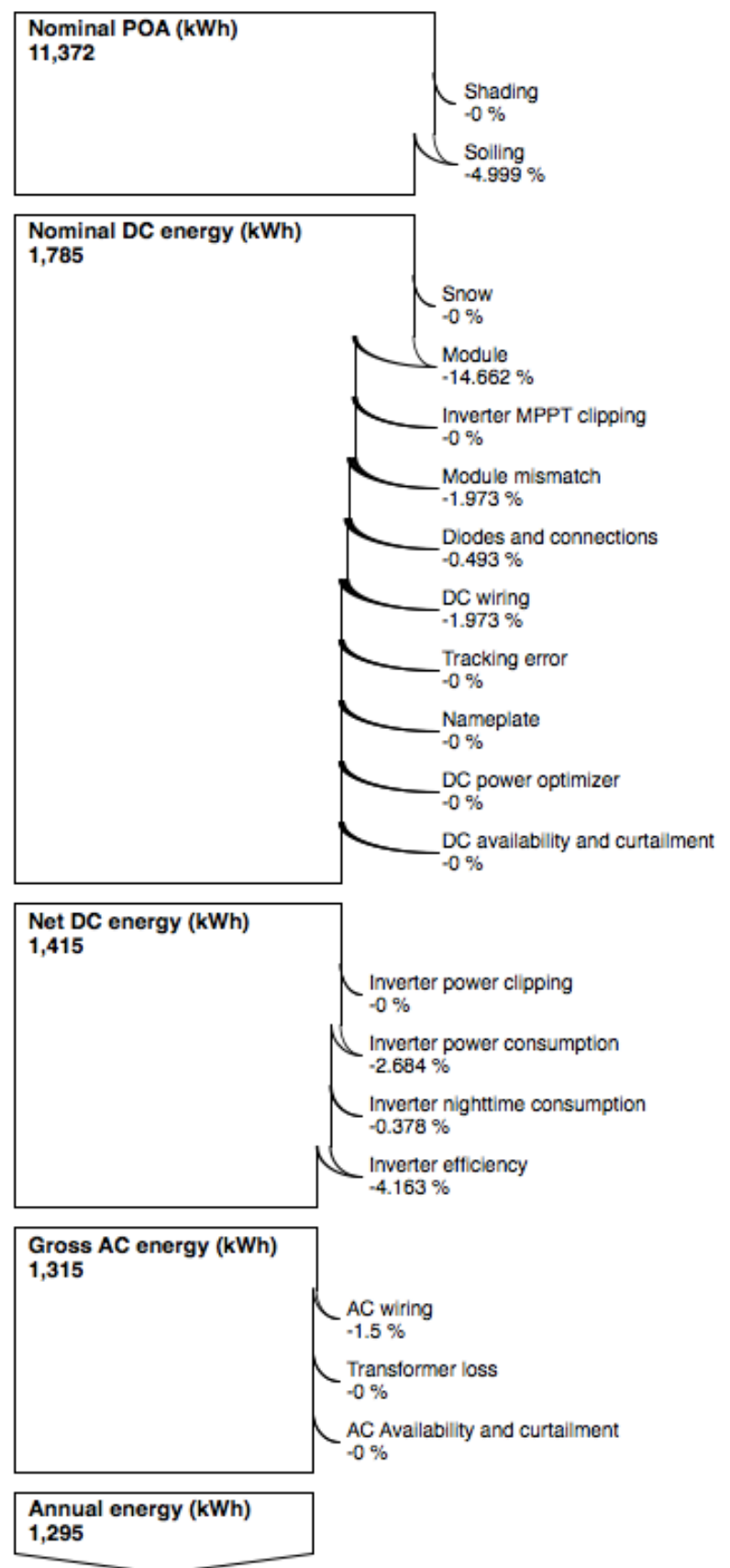


Se tratando de Energy Yield, o valor obtido pela simulação foi de $685 \mathrm{kWh} / \mathrm{kW}$, o que se mostra como um valor ligeiramente maior que na Instalação 2. De qualquer forma, está muito abaixo do que se espera para a cidade de Santos de acordo com Pereira et al. (2017), quando um sistema fotovoltaico é instalado com face voltada ao Norte Geográfico.

\section{4. Análise Comparativa}

Demonstrados os resultados de cada Instalação projetada, este tópico se reserva para comparação mais direta dos resultados. Sendo assim, a Tabela 11 mostra a comparação entre os resultados simulados. Em primeiro lugar, ressalta-se os fatores de capacidade de todas as três instalações que são valores bem baixos, estando abaixo do que foi apresentado nos leilões de energia de reserva de 2014, que estão na faixa dos 17\% (EPE, 2014). Isso se deve ao fato de que estes fatores de capacidade são encontrados em empreendimentos onde os níveis de irradiação são mais elevados, assim como menor nebulosidade. Desta maneira, os números obtidos estão dentro do esperado para a Instalação 1. Já para as Instalações 2 e 3, o fator de capacidade reduziu bastante e muito disso se deve a orientação dos módulos para o Sul geográfico.

Tabela 11: Resultados simulados para as Instalações 1, 2 e 3.

\begin{tabular}{lcccccc}
\hline & $\begin{array}{c}\text { Potência } \\
\text { Instalada } \\
(\mathrm{kW})\end{array}$ & $\begin{array}{c}\text { Geração } \\
\text { Anual } \\
(\mathrm{kWh})\end{array}$ & $P R$ & $\begin{array}{c}\text { Energy Yield } \\
(\mathrm{kWh} / \mathrm{kW})\end{array}$ & $\begin{array}{c}\text { Fator de } \\
\text { Capacidade }\end{array}$ & $\begin{array}{c}\text { LCOE } \\
(\mathrm{R} \$ / \mathrm{kWh})\end{array}$ \\
\hline Instalação 1 & 16,294 & 14.9 & 0,70 & 911 & $10,4 \%$ & 0,4376 \\
Instalação 2 & 2,281 & 1.5 & 0,63 & 674 & $7,7 \%$ & - \\
Instalação 3 & 1,890 & 1.3 & 0,69 & 685 & $7,8 \%$ & - \\
\hline
\end{tabular}

Já os valores de PR obtidos nas simulações se mostraram todos muito reduzidos. Porém, é necessário pontuar alguns aspectos com relação aos dados meteorológicos utilizados. A estação de coleta de dados mais próxima à cidade de Santos é a antiga estação da Ilha de Moela, localizada no Guarujá. A manipulação dos dados mostrou várias falhas por parte da coleta dos mesmos na estação, assim como o local em que ela estava instalada (entre duas elevações) restringia a coleta de dados de ventos em algumas direções, e com possível existência de sombreamento. Desta forma, estes fatores acabam prejudicando uma simulação mais realista das condições ambientais e de insolação no local de instalação do sistema 
fotovoltaico. Um estudo mais acurado poderá ser realizado no futuro com a instalação de uma estação meteorológica no Edifício Carvalho de Mendonça que possibilitará acesso a dados meteorológicos de maior confiabilidade. De qualquer forma, os dados se mostram coerentes quando comparamos as três instalações devido à orientação das mesmas.

Sendo assim, é do entendimento do autor que a simulação esteja subestimando de certo modo o PR e o fator de capacidade principalmente da Instalação 1, uma vez que os cálculos de sombreamento não possuem muita precisão, assim como os dados meteorológicos do local mostram inconstâncias.

\section{CONCLUSÃO}

As propostas para instalação dos sistemas fotovoltaicos no edifício Carvalho de Mendonça da Universidade Federal de São Paulo se mostram como investimentos não somente em eficiência energética e desenvolvimento sustentável, mas também como uma proposta de laboratórios de ensino e capacitação para os cursos do Departamento de Ciências do Mar.

Quanto aos resultados obtidos através do System Advisor Model (SAM), a ferramenta para determinação de sombreamento é pouco precisa e remete a dados com baixa confiabilidade, sendo necessária uma melhor avaliação deste parâmetro. Da mesma forma, os dados meteorológicos inseridos contêm apenas dados de irradiação global horizontal (GHI), enquanto que o ideal seria ter os valores de irradiação direta e difusa para uma melhor simulação. Sendo assim, sugere-se uma melhor avaliação do potencial solar na região a partir da instalação de uma pequena estação de coleta de dados e de imageamento de nuvens na cobertura do edifício para uma melhor precisão na simulação das plantas propostas no documento. A partir desta ideia, é possível que se obtenha estimativas mais confiáveis do fator de capacidade e de Performance Ratio (PR) para os sistemas fotovoltaicos apresentados.

Sugerimos como trabalhos futuros as determinações de sombreamento externo no entorno do edifício para uma melhor avaliação destes dados e dos seus impactos nos sistemas fotovoltaicos propostos. Outro estudo se refere às curvas de carga do edifício de forma a se analisar a produção do sistema com o consumo de energia elétrica ao longo do dia e assim realizar uma análise financeira mais precisa e detalhada dos fluxos de caixa, Valor Presente Líquido e Payback. 


\section{REFERÊNCIAS}

AGÊNCIA NACIONAL DE ENERGIA ELÉTRICA. Atlas de Energia Elétrica do Brasil. 3a Edição. ed. Brasília: [s.n.], 2008.

AGÊNCIA NACIONAL DE ENERGIA ELÉTRICA. Micro e Minigeração Distribuída: Sistema de Compensação de Energia Elétrica. 1a Edição. ed. Brasília: Caderno temáticos ANEEL, 2014. 28 p.

AGÊNCIA NACIONAL DE ENERGIA ELÉTRICA. Micro e Minigeração Distribuída: Sistema de Compensação de Energia Elétrica. 2 a Edição. ed. Brasília: Cadernos temáticos ANEEL, 2016.

AGÊNCIA NACIONAL DE ENERGIA ELÉTRICA. Banco de Informação de Geração. ANEEL, 2017. Disponivel em: <http://www.aneel.gov.br>. Acesso em: 10 setembro 2017. AGÊNCIA NACIONAL DE ENERGIA ELÉTRICA. Mini e Microgeradores conectados à rede. ANEEL, 22 agosto 2017. Disponivel em: $<$ http://www.aneel.gov.br $>$. Acesso em: 22 agosto 2017.

ALVES, L. V.; CUNHA, L. A.; SILVA, R. M. Análise dos Custos de Estações Fotovoltaicas no Nordeste do Brasil. XXXV Encontro Nacional de Engenharia de Produção, p. 12, Outubro 2015.

CANADIAN SOLAR. Solar panels. Disponivel em: $<$ https://www.canadiansolar.com $>$. Acesso em: Outubro 2017.

COLLE, S.; ABREU, S. L.; RÜTHER, R. Economic evaluation and optimization of hybrid diesel/photovoltaics systems integrated to utility grids. Solar Energy, 76, 2004. 295-299. EMPRESA DE PESQUISA ENERGÉTICA. Nota Técnica: Análise da inserção da geração solar na matriz elétrica brasileira. EPE. Rio de Janeiro. 2012. EMPRESA DE PESQUISA ENERGÉTICA. Nota Técnica: Demanda de Energia 2050. EPE. Rio de Janeiro. 2014.

EMPRESA DE PESQUISA ENERGÉTICA. Nota Técnica: Leilão de energia de reserva de 2014. EPE. Rio de Janeiro. 2014.

FIALHO, L. et al. Effect of Shading on Series Solar Modules: Simulation and Experimental Results. Procedia Technology, 17, 2014. 295-302.

GOLDEMBERG, J.; LUCON, O. Energia e meio ambiente no Brasil. Estudos Avançados, 21, n. 59, 2007. 9-20.

INTERNATIONAL ENERGY AGENCY. Key World Energy Statistics. Paris: [s.n.], 2016. LU, F. et al. Improved PV Module Performance Under Partial Shading Conditions. Energy Procedia, 33, 2013. 248-255.

MIASOLÉ. Disponivel em: <http://www.miasole.com>. Acesso em: Outubro 2017. MINISTÉRIO DE MINAS E ENERGIA. Balanço Energético Nacional. Empresa de Pesquisa Energética. Rio de Janeiro, p. 292. 2016.

OLIVEIRA, S. H. F.; ZILLES, R. Grid-connected Photovoltaic Systems: The Brazilian Experience and the Performande of an Installation. Progress in Photovoltaics: Reserach and Applications, 9, 2001. 341-347.

OPERADOR NACIONAL DO SISTEMA ELÉTRICO. Situação dos principais reservatórios do Brasil. ONS, 2017. Disponivel em: <http://www.ons.org.br>. Acesso em: 10 Setembro 2017.

PEREIRA, E. B. et al. Atlas Brasileiro de Energia Solar. 1a Edição. ed. São José dos Campos: INPE, 2006. 60 p.

PEREIRA, E. B. et al. Atlas Brasileiro de Energia Solar. 2a Edição. ed. São José dos Campos: INPE, 2017. 88 p. 
PINHO, J. T.; GALDINO, M. A. Manual de Engenharia para Sistemas Fotovoltaicos. Rio de Janeiro: CEPEL - CRESESB, 2014. 528 p.

RAZYKOV, T. et al. Solar photovoltaic electricity: Current status and future prospects. Solar Energy, 85, 2011. 1580-1608.

REICH, N. H. et al. Performance ratio revisited: is PR $>90$ realistic? Progress in

Photovoltaics: Research and Applications, 20, 2012. 717-726.

SHARMA, D. K.; VERMA, V.; SINGH, A. P. Review and Analysis of Solar Photovoltaic Softwares. International Journal of Current Engineering and Technology, 4, n. 2, 1 abril 2014. 725-731.

YINGLI SOLAR. Produtos. Disponivel em: $<$ https://www.yinglisolar.com>. Acesso em: Outubro 2017. 